\title{
Comparative analysis of key socio-economic and environmental impacts of smallholder and plantation based jatropha biofuel production systems in Tanzania
}

\author{
Janske van Eijck ${ }^{a, *}$, Henny Romijn ${ }^{b}$, Edward Smeets ${ }^{a, c}$, Rob Bailis ${ }^{d}$, \\ Martijn Rooijakkers ${ }^{b}$, Nelleke Hooijkaas ${ }^{a}$, Pita Verweij ${ }^{a}$, André Faaij ${ }^{a}$ \\ ${ }^{a}$ Utrecht University, Copernicus Institute, The Netherlands \\ ${ }^{\mathrm{b}}$ Eindhoven University of Technology, The Netherlands \\ ${ }^{\mathrm{c}}$ LEI Part of Wageningen - UR, The Netherlands \\ ${ }^{\mathrm{d}}$ Yale School of Forestry and Environmental Studies, UK
}

\section{A R T I C L E I N F O}

Article history:

Received 1 May 2012

Received in revised form

25 July 2013

Accepted 4 October 2013

Available online 19 December 2013

Keywords:

Jatropha

Sustainability

Socio-economic

Tanzania

Food security

Business model

\begin{abstract}
A B S T R A C T
Two jatropha business models are compared on seven key sustainability areas of concern, which are operationalized into various quantitative and qualitative indicators. The assessment is based on two Tanzanian real-life cases, a wide range of primary and secondary sources are used. Results indicate that both the decentralized smallholder model and the centralized plantation model can lead to positive socio-economic and environmental impacts, but substantial differences are also apparent. The smallholder model scores better on land rights, GHG balance and biodiversity and it reaches more people, whereas the plantation model creates more employment and higher (local prosperity) benefits for smaller numbers of people, and could lead to higher yields. Negative impacts of the smallholder model are minimal, whereas the plantation model could lead to decreased food security, loss of land rights and biodiversity. This could permanently affect the livelihood situation of the local population, but this is not inevitable as there is considerable scope for implementing mitigating policies. The way in which a particular model is implemented in practice, its management and company values, can have a major influence. However, the biggest hurdle towards achieving sustained positive societal impacts in both models is their marginal profitability at current yields, costs and prices. Still, these results are highly sensitive to uncertain yields and oil prices. Better outcomes in the future are therefore not foreclosed. A reliable sustainability assessment requires many location-specific and operational company data. More quantitative indicators are ideally required to improve assessment of social impacts and effects on environment.
\end{abstract}

(c) 2013 Elsevier Ltd. All rights reserved.

\section{Introduction}

The use of biofuels can potentially contribute to climate change mitigation, rural development and energy security.
One source for biofuel is jatropha, a perennial shrub that grows pan tropically, whose seeds contain oil that can be used as a diesel substitute. Early this century jatropha attracted a great deal of attention by investors [1-4]. Allegations about

* Corresponding author. Utrecht University, Copernicus Institute, Faculty of Geosciences, Heidelberglaan 2, 3584 CS Utrecht, The Netherlands. Tel.: +31 302537648; fax: +31 2537601.

E-mail address: J.A.J.vanEijck@uu.nl (J. van Eijck).

0961-9534/\$ - see front matter @ 2013 Elsevier Ltd. All rights reserved.

http://dx.doi.org/10.1016/j.biombioe.2013.10.005 
yields of up to $10 \mathrm{t}$ seeds ha $\mathrm{h}^{-1}$ [5], or $5 \mathrm{t}$ seeds $\mathrm{ha}^{-1}$ on average [6], low nutrient requirements, and little need for care in combination with ability to withstand semi-arid conditions raised high expectations regarding its Straight Vegetable Oil (SVO) and biodiesel potential [7]. But the realized plantings have been much more modest. The global financial crisis caused difficulties in financing. More accurate research also emerged, warning that realistic yields from an undomesticated crop would be only around $1000 \mathrm{~kg}$ seeds ha ${ }^{-1}$ [8], and that the crop would not perform in poor conditions without adequate nutrient and water management [9]. Concerns were also raised about socio-economic impacts of large plantations, especially local food security $[10,11]$. Positive livelihood impacts on smallholders also began to be questioned, mainly due to severely disappointing yields [12].

However, that does not mean that jatropha projects cannot have positive effects at all. So far, study results have remained inconclusive, partial, and in mutual disagreement on many fronts. There is a definite lack of studies assessing project sustainability comprehensively. For instance, although several studies have reviewed agronomic aspects, livelihood impacts and/or the economic viability of several jatropha case studies [7,13-16], they have not examined ecological impacts. Other studies have looked at environmental aspects $[17,18]$ and land rights [19], but without assessing economic viability. Comparisons of the two most common business models, plantations and smallholder systems, are particularly scarce, although some studies suggest major impact differences [7,20,21]. One major obstacle is that big plantations are wary to share key financial performance data. Only a few studies, all focused on Mozambique, have reviewed impacts by large plantations [22-24], but these studies are not comparative since hardly any smallholder projects operate there. Broadhurst's Tanzanian study [25] is a good comparative attempt, but his study lacks an economic viability assessment. Many studies also have not used systematic qualitative and quantitative impact indicators.

This article aims to conduct a methodologically rigorous and detailed comparative assessment of the major socioeconomic and environmental impacts caused by two major different jatropha business models, using two projects operating in Tanzania as case studies: a large centralized plantation and a smallholder (hedge) system organized around a central processor. In order to create a comprehensive and yet practically applicable list of sustainability indicators, we identified "seven key areas of concern" that are mentioned by different sustainability certification initiatives. For each of these, qualitative and - as much as possible - quantitative impact indicators were formulated. Data were drawn from a wide range of published and grey literature, company documents, personal interviews, satellite data and own field measurements. A mix of quantitative and qualitative methods was used to assess the impacts of the projects according to the chosen indicators. This included, among others, detailed financial feasibility estimations and GHG estimations, including land use change effects. Primary data collection took place in May-August 2010 at the plantation company and during 2006-2010 at the oil processor that coordinates the smallholder system.

The principles, criteria, indicators and methods used in the analysis are described in Sections 2.1 and 2.2. Then follows a description of the plantation and smallholder-based models in Section 2.3. Section 3 presents the results of the analysis for each of the seven areas of concern. Section 4 contains the discussion and conclusions. Methodological details and background statistics are provided in the online supplementary material.

\section{Approach and methodology}

\subsection{Selection of principles, criteria and indicators}

The principles/criteria and indicators/parameters shown in Table 1 were derived from various certification initiatives, policy documents and scientific literature in which the sustainability of bioenergy systems is researched (see Ref. [26] for a comprehensive review of such initiatives in 2010). In some certification systems a distinction is made between (more general) principles and (more specific) criteria. However, this distinction is often vague; therefore we use a combined category "principles/criteria".

A large number of certification initiatives are being developed and applied. These initiatives vary with respect to scope, issues addressed, and criteria and indicators included. Our focus is on widely recognized frameworks such as: the Cramer criteria [27,28] operationalized in the NTA8080 [29], the Roundtable on Sustainable Biofuels (RSB) [30] and the Global Bio Energy Partnership (GBEP) [31]. We also examined the Renewable Energy Directive (RED) of the European Commission [32], the Position Paper of the WWF with options to promote sustainability [33] and the Draft National Biofuels Guidelines of Tanzania [34]. The RSB is currently considered as one of the most widely acknowledged and most comprehensive certification schemes $[26,35,36]$. In July 2011, the European Commission officially recognized its compliance with its Renewable Energy Directive 2009/28/EC [37-39]. The GBEP has compiled 24 sustainability indicators (May 2011) which are currently being operationalized and also widely acknowledged $[31,40]$. We deliberately did not confine ourselves to using one specific system, as this would be arbitrary and might result in a potentially biased assessment. Moreover, socio-economic impacts of bioenergy production are hardly included in existing initiatives, despite serious concerns [26]. We did want to address socio-economic issues in this study.

First, the areas of concern were identified that are most frequently mentioned in these certification initiatives and in the scientific literature (see $[41,117]$ for an overview of all potentially relevant areas of concern). A few of those, especially water, soil, air and gender issues, could not be taken into account in this study due to data constraints for the two projects in Tanzania and a lack of suitable indicators. For each chosen area of concern one or more principles/criteria were then selected (Table 1).

For each principle/criterion one or several concrete, measurable indicators were defined or compiled, which are used to evaluate to what extent the principles/criteria are met. For working and labour conditions, only compliance or descriptive indicators were selected because it is not possible to compile measurable indicators for this area of concern (see e.g. Ref. [48] for a discussion about the use of indicators). The selection and formulation of principles/criteria and the definition of indicators are detailed below for each area of concern. 
Table 1 - Overview of principles/criteria, indicators/parameters, method of analysis, and data sources used in the analysis (sources: [27,31-34,39-42]).

\begin{tabular}{l} 
Principle/criteria \\
\hline The production of bioenergy \\
shall: \\
$\begin{array}{l}\text { Socio-economic areas of concern } \\
\text { 1. Economic feasibility }\end{array}$ \\
Be financially feasible
\end{tabular}

1. Economic feasibility Be financially feasible

2. Local prosperity

Contribute to the social and economic and indigenous peoples and communities

3. Labour and working conditions

Ensure decent work and the well-being of workers

4. Food security Not endanger food security

5. Land ownership and land rights ${ }^{f}$

Not violate land rights

Environmental areas of concern

6. Greenhouse

gas balance

and carbon

stock changes

Contribute to reducing GHG emissions compared to

fossil

fuels and contribute to

reducing

fossil fuel use

7. Biodiversity development of local, rural

NPV $\left[\$ \mathrm{ha}^{-1}\right]^{\mathrm{a}}$, IRR $[\%]^{\mathrm{a}}, \mathrm{PBP}[\mathrm{yr}]^{\mathrm{a}}$, production costs $\left[\$ 1^{-1}\right]^{a}$. NPV and IRR should be positive and PBP and production costs competitive

Wages and employment: Employment opportunities, unemployment rate in the region, additional income for smallholder, wage categories for employees [\$]. Impact on local economy: Total investment costs [\$], total (discounted) costs [\$], investments in health care and education facilities, infrastructure, purchase of local materials, expenses that stay in local economy [\%], origin of employees ${ }^{\mathrm{c}}$ : region or nation of origin

social wellbeing: perception of local population, risks for population if project is abandoned

Compliance to and description of: legal issues, child labour provisions, discrimination, forced and compulsory labour, disciplinary practises, safety, freedom of trade union organization, education/training. working hours, secondary benefits

Qualitative description of; current food security status, possible threats to decreased food availability, access, stability and utilization and measures taken to increase food security Land procurement procedures; land transferred [ha], compensation payments [\$]; displacement of people; process transparency; risk in case of discontinuation; public opinion

Above- and below-ground carbon stock; life-cycle $\mathrm{GHG}$ emissions $\left[\mathrm{CO}_{2}\right.$-eq]

\section{Shall avoid negative} impacts on biodiversity, ecosystems, and areas of high conservation value

Conversion of vegetation; location of production areas related to various biodiversity maps; occurrence of threatened species; species diversity (Shannon, Sørenson index)
GIS analysis, observations and literature.
Quantitative

(economic

modelling)

Qualitative and quantitative

Qualitative

Qualitative and quantitative

Qualitative

Literature, observations.

Fieldwork

(in 2006-2010) and company documents.

\section{Company}

business plans, interviews with the communities, literature including household surveys, and national statistics.

Company documents, literature, visits and interviews with management.

Statistical data, literature and observations.

Quantitative

At plantation site: satellite data calibrated with field measurements.

Qualitative and quantitative

\footnotetext{
${ }^{a}$ A Net Present Value (NPV) $>0$ and an Internal Rate of Return (IRR) $>$ the (real) discount rate, constitute minimum requirements for project profitability, as well as a reasonable Pay Back Period (PBP), the number of years needed to recover the initial project investment. The total production costs per litre SVO are useful for comparing efficiency of the two business models. They mainly comprise investments in farming support, processing, storage/transport and general investments. For calculation of the total production costs per litre, fixed investment costs are levelised over the 20 year project period. For formulae, see Ref. [43].

b Background indicators used for local prosperity: Gross Domestic Product (GDP); GINI coefficient [44]; Human Development Index (HDI) [44]; \% people below the Tanzanian national poverty line; \% people below US $\$ 2.00$ per day [45,55]; \% people below the extreme poverty line of US\$1.25 (PPP) [44] Multidimensional Poverty Index [44]; Poverty Gap Ratio [46]; minimum wage [\$]; \% own-account and contributing family workers in total employment, based on Ref. [46] household possessions; and literacy rate [\%]. Definitional details in Appendix B in the online supplementary material. c The origin of the employees is analysed to see if the wages earned are likely to be spent in the local economy, or that they are likely to leak out to other countries/regions.
} 
d These indicators are based on the UN Universal Declaration of Human Rights (1948), which is a requirement by the NTA8080 [29] and the "Tripartite Declaration of Principles concerning Multinational Enterprises and Social Policy", set up by the International Labour Organization [47]. Other benefits: [42]. Safety is also mentioned by [40,41].

e Background indicators used for food security: food security situation Tanzania; change in production of main staple crops [\%]; food price index, change compared to overall price index [\%].

${ }^{\mathrm{f}}$ Background indicators used for land rights: number of land certificates handed out; number of land conflicts; dissolving rate.

\subsection{Description of main indicators and assessment methods}

\subsubsection{Economic feasibility}

In order to assess the economic sustainability of our cases we conduct a Cost Benefit Analysis (CBA), in which the Net Present Value (NPV), the Internal Rate of Return (IRR) and the Pay Back Period (PBP) are used as indicators $[49,43]$. The CBA is performed assuming similar total cultivation areas of 80,000 ha and a 20 year lifespan for both cases. The 80,000 ha corresponds to the original business plan of the plantation company and is also broadly compatible with the goals set by the processor in the smallholder-based system [72,77]. The 80,000 ha size assumption is also used to assess impacts on local prosperity, food security and the environment.

In the plantation model, the choice of harvesting system is expected to have a large impact on total employment, and thereby on regional economic impacts. Therefore, two harvest-system scenarios are worked out for this model: "semi-manual" and "fully- mechanized". For the smallholderbased system, two different capacity scenarios are elaborated: a "low" base case (88,000 tons of processed seed/year) and a "high" case (160,000 tons of seeds/year). The "low" scenario assumes a low-input cultivation regime and low per-ha yields for the smallholders, whereas the "high" scenario is compatible with intermediate input cultivation [43].

A sensitivity analysis is performed with respect to $\mathrm{CO}_{2}$ credit price, SVO price, discount rate, and - for the smallholder model - the purchase price of seeds. In the plantation system various yield scenarios are analysed, as well as a scenario in which proceeds from harvested wood from land clearing are incorporated (as stipulated in the original business plan). A full list of CBA assumptions is contained in Appendix A in the online supplementary material.

\subsubsection{Local prosperity}

Local prosperity can be increased if household income is increased through employment or increased earnings. The focus in this analysis is on income-effects from employment and their impacts on the local economy. Furthermore, a qualitative description of the impact on social well-being is added. Because the projects had not reached their full size at the time of this assessment, this analysis is partly prospective.

\subsubsection{Labour and working conditions}

Labour and working conditions relate to the way hired employees are treated, and how smallholders could be influenced in their working conditions. Most of the indicators are compliance indicators: the presence of specific policies on discrimination, disciplinary procedures and the possibility to join a labour union was checked. Various operational company data were used for this.

\subsubsection{Food security}

It is explored if either model of biofuels production threatens to decrease food security in any way, or, if so, how the scheme proposes to mitigate the threats. The RSB proposes that biofuel producers take measures to "enhance the local food security of the directly affected stakeholders" [50]. Therefore, it is also explored whether the scheme proposes to improve food security beyond current levels. The current status of the case study regions along the spectrum of food insecurity and malnutrition is investigated first. This is done with biometric measures taken from existing data sources: weight-for-age [51,52]; wasting or stunting; and vulnerability. Vulnerability is determined by looking at the five vulnerable livelihood groups that are identified in Tanzania by McKinney [51]; poor-income people (income mostly from crop production), wage labourers, small farmers, remittance dependents and natural resource dependents. Threats to food security arising from the projects are analysed next, by looking at its different dimensions distinguished by FAO: availability, access, stability of supply, and utilization of food for individuals, households, communities and larger population groupings $[53,54]$. Stability of food supply relates to both availability and access. If groups are affected through big changes in either price or access to supply, then they lack stability and may suffer from food insecurity [55]. Utilization relates to food quality, preparation, and storage, as well as nutritional knowledge and health status of the population [55]. Biofuel activities could affect this through impacts on availability of essential inputs to food preparation, like water and fuel.

\subsubsection{Land ownership}

In African countries land rights are typically embedded in complex legal frameworks [56]. In Tanzania informal customary land laws co-exist with formal land title deeds, which is why transferring land is complex and sensitive. The main issues are: the land acquisition process (possibly involving deviations from legally established routes); land compensation payments (undervaluing the land); transparency of the process (possibly leading to misunderstandings and disagreements about compensation eligibility); and impacts on livelihoods [56-58]. Furthermore, promises made by projects to villagers are often not written down and therefore cause scepticism amongst farmers when expectations are not met [58]. Therefore the following processes are evaluated: land procurement procedure; change in land access; amount of ha transferred; compensation paid; transparency of process; potential risk in case of project failure; and public opinion in Tanzania. Our main data sources were operational company data and external reports.

\subsubsection{GHG balance and carbon stock}

Standard GHG methodology is used, e.g. Ref. [59]. In the smallholder system, GHG emissions from changes in 
above or belowground biomass, soil organic matter and litter are negligible, assuming jatropha is planted as hedgerows in addition to current crop cultivation, thus avoiding conversion of forest and existing cropland. For (large scale) plantations, the emissions from changes in land use are evaluated by estimating the difference in carbon stock between the prior natural vegetation and the jatropha plantation. The carbon stock of the natural vegetation is estimated as follows:

- Aboveground biomass is calculated using remote sensing data in combination with field measurements, as applied by e.g. Refs. [60,61]. A satellite map was used to calculate the Normalized Difference Vegetation Index (NDVI), this is validated by measuring the harvested and dried aboveground biomass of 10 plots $(20 \times 20 \mathrm{~m})$ for each of the four most common vegetation classes which are woodland, open forest, forest and dense forest (so 40 plots in total). Where available, specific wood densities were used to determine the carbon stock of trees. Shrubs and small trees were weighed and dried in a kiln to calculate the dry biomass per ha. Grass was sampled in subplots of 5 by $5 \mathrm{~m}$, and sundried. The aboveground biomass measurements were linked to the NDVI values from remote sensing by means of a linear regression analysis. Next, the NDVI map was converted into an aboveground carbon map using the regression equation: $\mathrm{NDVI}=(\mathrm{NIR}-\mathrm{VIS}) /(\mathrm{NIR}+\mathrm{VIS})$ in which NIR is the near infrared part of the spectrum, and VIS is the visible part of the spectrum of light [62]. This map is used to calculate the total carbon stock of the area assuming all carbon in the biomass is emitted as $\mathrm{CO}_{2}$ when the land is cleared for the jatropha plantation.

- Belowground biomass is estimated using the data on above ground biomass and the default IPCC factors for the above/belowground biomass ratio.

- Dead organic matter (dead wood and litter): value taken from literature.

- Soil organic matter (carbon in soil): value taken from literature. The timeframe for inclusion of the change in carbon stock is 20 years.

The GHG reduction is then calculated using formula (1) below.

GHGreduction $(\%)=\frac{F-(-A+B-C-D-E)}{F} * 100$

GHG emissions/absorption from:
A: Removal of original vegetation
B: Jatropha growth
C: Transport
D: Conversion to jatropha oil
E: Transport to end-user
F: Application of the jatropha oil/fossil reference

Values from literature are used to determine lower and upper ranges for each item, the timeframe is 20 years. No useful application of the removed vegetation, mainly hulls used as a fertilizer, and seedcake used as a fertilizer, is assumed except for the upper range calculations.

\subsubsection{Biodiversity}

One of the key strategies to mitigate the risk of bioenergy projects to biodiversity is to conserve areas of significant biodiversity value [63]. The risk of plantation establishment to areas of significant biodiversity value is assessed by identifying the location of national protected areas [64]. Furthermore, additional areas of significant biodiversity value are considered, as identified by Biodiversity Hotspot Areas [65], Key Biodiversity Areas according to Birdlife International [66], and Critical Ecoregions [67]. The location map of the plantation was overlaid with these maps. Overlap indicates potential risk of reduced biodiversity if the land is converted to biofuel cultivation.

The shrub and tree diversity of the planned plantation area are assessed using the Shannon-index [68] to account for abundance and evenness of the species present, and the Sorensen-index [69] to indicate similarities between vegetation types; see Appendix $\mathrm{F}$ in the online supplementary material for the formulae. These two indexes do not have a threshold value but are compared to values reported in the literature, to assess the degree of degradation of the initial vegetation.

Conversion of natural vegetation into plantations containing species with limited distributions could result in (local) species extinction. Therefore, the presence of endangered and endemic species is evaluated by indicating in the 40 plots that were assessed, all trees exceeding a DBH of $10 \mathrm{~cm}$ with their Kiswahli names with the help of a local expert followed by identification of their botanical names. The species names are checked with the IUCN Red List of Threatened Species [70].

The indicators used to assess impacts on biodiversity can thus be compared to elements of the concept of a high conservation value (HCV) area initially developed by the Forest Stewardship Council (FSC 1996) in its standard on sustainably managed forests. This concept includes different conservation values of global and national importance that are based on species, sites, ecosystems, and values corresponding to ecosystem services, in particular HCV criteria $1-3[71]$.

\subsection{Selection and description of the two bioenergy production systems and settings}

\subsubsection{Case study region}

Two Tanzanian cases were chosen for the following reasons: first, in Tanzania there are different jatropha business models in operation which makes the comparison realistic. Second, jatropha projects in this country started as early as 2005, so a lot of experience has accumulated. Third, the Tanzanian government has been working on an enabling environment for biofuels and is distinguishing in its policies between plantations and smallholder schemes [34]. Two real-life jatropha production systems were investigated: a plantation company in the Southeast of Tanzania, BioShape Tanzania Ltd., and a decentralized smallholder system with a central oil processor located in the North of Tanzania, Diligent Tanzania Ltd. The smallholder system covers a much larger sourcing area than the concentrated plantation, see Fig. 1. 


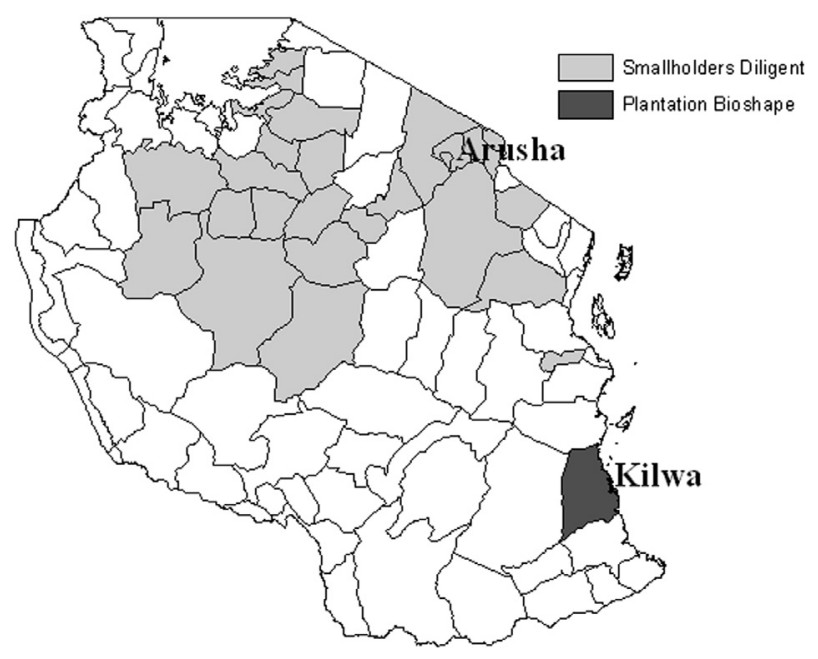

Fig. 1 - Overview of Tanzanian districts that are covered by Diligent Tanzania Ltd. (smallholders) and BioShape (plantation) in 2009.

\subsubsection{Smallholder (hedgerow) system}

In the smallholder (hedgerow) system, farmers produce for the processing company either under contract (also called outgrowing or contract-farming) or independently. Mostly, family labour is used. The jatropha hedgerows are planted around homesteads or agricultural plots. One farmer can plant the equivalent of around $0.5-1$ ha with jatropha, with on average 1000 plants per plot. The seeds are sold to the processor company directly or through a collector who adds a commission to the seed price. Cultivation of jatropha is not very profitable for smallholders, but in many cases it is attractive enough due to low opportunity costs for labour and hedge land [43].
Collection centres run by collectors are located near strategic places such as in a grocery shop, a school or at the house of a well-known farmer. Farmers bring their seeds in bags using bicycles, ox-charts or other local forms of transport. The company organizes onward seed transport to the central processing unit in Arusha, using local transport companies. A "backhaul system" is used for this, utilizing trucks that would otherwise return empty to town after delivering their products upcountry. The processor provides the farmers and collectors with extension services and initial planting material (farming promotion). The processor employs a field team for promotion of the crop, and technical staff in the factory. The processed products are used for the domestic and international market.

Diligent started its activities in 2005 and continued to the end of 2012 when one major investor pulled back. The activities, collection and processing, still continue but under new ownership and name. At the time of study in 2006 the company was working with around 4000 smallholders (reaching 40,000 by 2011), produced around 35,000 I SVO annually and employed around 35 people. The goal at the time of study was to reach 10,000 and ultimately $50-200,000$ ha over 20 years; an expansion to 80,000 ha is assumed here to enable comparison with the plantation.

\subsubsection{Plantation system}

In the plantation system the land is owned by the company Bioshape and hired employees cultivate monoculture (block) plantations of 200 ha each. Agricultural equipment and trucks used for cultivation and transport are also owned by the company. Harvesting is done semi-manually, with tree shakers (=our base case scenario). Fully mechanized harvesting is also considered, but these technologies are not yet fully developed. The original business plan envisaged export of unprocessed seeds to Europe, but later plans allowed for

Table 2 - Key characteristics of the two business models used in the analysis.

Business model $\rightarrow \quad$ Smallholder-based model Plantation model

Characteristic $\downarrow$

\begin{tabular}{|c|c|c|}
\hline Mode of planting & Hedgerows & Monoculture \\
\hline Type of labour & $\begin{array}{l}\text { Family labour or occasional hired labour on the farms, and } \\
\text { employees in the processing factory and field team }\end{array}$ & Employees \\
\hline Area under cultivation & 80,000 ha & 80,000 ha \\
\hline Beneficiaries & $\begin{array}{l}80,000-160,000 \text { farmers (each } 0.5-1 \text { ha) and employees } \\
\text { ( } \approx 500 \text { est.) }\end{array}$ & Employees $(10-35,000)$ \\
\hline Yield & $\begin{array}{l}1.1 \text { ton } \mathrm{ha}^{-1} \mathrm{yr}^{-1} \text { as the base case ('low' yield scenario), or } \\
2 \text { ton } \mathrm{ha}^{-1} \mathrm{yr}^{-1} \text { ('high' yield scenario), see Ref. [43] }\end{array}$ & $\begin{array}{l}1.1 \text { ton } \mathrm{ha}^{-1} \mathrm{yr}^{-1} \text { as the base case; } \\
2,4 \text { and } 6^{\mathrm{a}} \text { ton } \mathrm{ha}^{-1} \mathrm{yr}^{-1} \text { in the sensitivity } \\
\text { analysis }\end{array}$ \\
\hline Processing capacity & $\begin{array}{l}88,000 \text { ton seeds } \mathrm{yr}^{-1} \text { as the base case (low yield scenario) } \\
160,000 \text { ton seeds } \mathrm{yr}^{-1} \text { (high yield scenario) }\end{array}$ & $\begin{array}{l}88,000 \text { ton seeds } \mathrm{yr}^{-1} \text { as the base case; } \\
\text { reaching up to } 480,000 \text { ton seeds } \mathrm{yr}^{-1} \text { at } \\
6 \text { ton } \mathrm{ha}^{-1} \mathrm{yr}^{-12} \text { in the sensitivity } \\
\text { analysis }\end{array}$ \\
\hline Mode of harvesting & Fully manual & $\begin{array}{l}\text { Semi-manual (base case) or fully } \\
\text { mechanized }\end{array}$ \\
\hline Processing & In Tanzania & $\begin{array}{l}\text { Initial plan: Western Europe; later } \\
\text { changed to Tanzania [34] }\end{array}$ \\
\hline Products & Jatropha SVO and biodiesel, seedcake briquettes and charcoal & $\begin{array}{l}\text { Jatropha SVO and biodiesel, seedcake } \\
\text { briquettes and charcoal, jatropha seeds, } \\
\text { harvested wood from plantation }\end{array}$ \\
\hline
\end{tabular}


domestic seed processing, as requested by the Tanzanian Ministry of Energy and Minerals [34]. At the time of study (2009) BioShape had planted 400 ha, acquired 34,000 ha, and employed around 400 casual and contract workers. It aimed at 80,000 ha under cultivation by 2018 [72]. By the end of 2010 activities halted for various reasons, amongst others the financial crisis. However, the financial model reported here is based on the assumption of a fully executed business plan.

More details about the business models are given in Table 2.

The analysis includes land clearing and preparation (plantation only), the production and transport of the feedstock, conversion into biofuel, and transport to end users.

\section{Table 3 - Main results of the economic analysis.}

\begin{tabular}{|c|c|c|c|c|}
\hline System & $\begin{array}{c}\text { NPV } \\
\left(\mathrm{US} \$ \mathrm{~m} \mathrm{ha}^{-1}\right)\end{array}$ & IRR (\%) & PBP (yr) & $\begin{array}{c}\text { Discounted } \\
\text { production } \\
\text { costs } \\
\text { US } \$ / 1 \text { SVO }\end{array}$ \\
\hline \multicolumn{5}{|l|}{ Plantation } \\
\hline $\begin{array}{l}\text { Semi-manual } \\
\text { ( } 1 \mathrm{t} / \mathrm{h}) \text {, base } \\
\text { case }\end{array}$ & 15 & 17 & 13 & $1.32^{\mathrm{a}}$ \\
\hline $\begin{array}{l}\text { Fully } \\
\text { mechanized } \\
(1 \mathrm{t} / \mathrm{h})\end{array}$ & -3 & 7 & $\geq 20$ & 1.45 \\
\hline \multicolumn{5}{|c|}{ Processing with smallholders } \\
\hline $\begin{array}{l}\text { Low capacity } \\
82,000 \text { ton } \\
\text { seeds, base } \\
\text { case }\end{array}$ & 8 & 14 & 13 & 1.28 \\
\hline $\begin{array}{l}\text { High capacity } \\
160,000 \text { ton } \\
\text { seeds }\end{array}$ & 18 & 18 & 12 & 1.20 \\
\hline
\end{tabular}

Applications considered are Straight Vegetable Oil (SVO) for local use and export (both models). Co-products from biofuel production - seedcake and husks - are used as alternatives to wood and/or charcoal, e.g. in boilers, and as a fertilizer. The timeframe of our analysis runs from 2005 to 2025, when both models reach maximum production capacity with mature trees.

\section{Results}

\subsection{Economic feasibility}

The results of the economic analysis are presented in Table 3 and Fig. 2. The total investment costs (excluding general expenses) amount to US $\$ 11 \mathrm{~m}$ for the smallholder model and US $\$ 32 \mathrm{~m}$ for the plantation. The total (discounted) costs over a 20 year lifetime are US\$77-130 $\mathrm{m}$ for the smallholder model and US\$ 107-125 $\mathrm{m}$ for the plantation.

With (semi)manual harvesting, both business models are marginally profitable. Interestingly, these base case profitability estimations for the two models are quite similar, even though their land, capital and labour configurations differ considerably.

The estimated PBPs of 12-13 years are long especially in the context of developing economies where risks are high, and even more so in view of the lack of commercial experience with jatropha as an energy crop. Both base case models have low IRRs: The low capacity smallholder system with yields of 1.1 ton seeds $\mathrm{ha}^{-1} \mathrm{y}^{-1}$ has an IRR of $14 \%$, and the plantation with the same yield and semi-mechanized harvesting yields $17 \%$. This is dangerously close to the real discount rate of $8.2 \%$. The best IRR of $18 \%$ occurs in the "high" scenario of the smallholder model. Fully mechanized harvesting in the plantation model is expected to be unprofitable. However, the plantation profits are much higher if wood sales from land

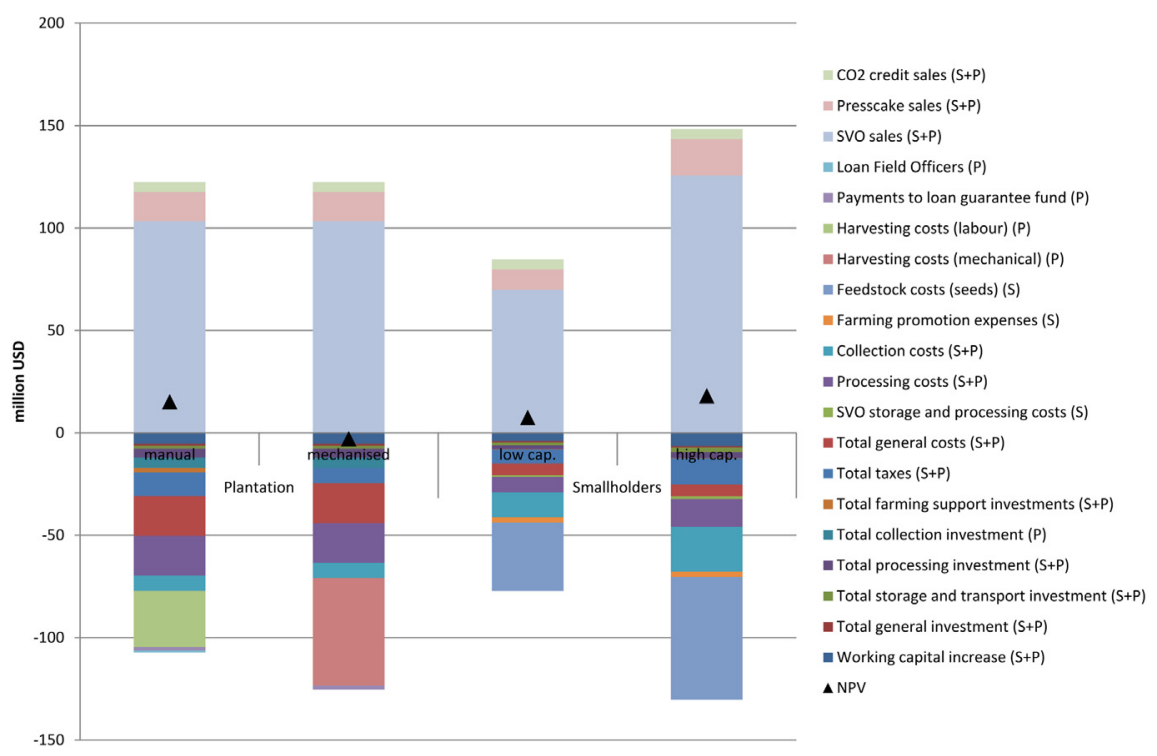

Fig. 2 - Discounted production costs, revenues and NPVs for the two models (2 scenarios each). S indicates cost factors specific to the smallholder model, while $P$ indicates plantation-specific cost factors. $S+P$ means that the relevant cost factors apply to both models. 
Table 4 - Sensitivity of profitability to changes in $\mathrm{CO}_{2}$ credit revenue, svo price, discount rate, seed purchase price, seed yield and the inclusion of wood sales $(\mathrm{Pl}=$ plantation model, $\mathrm{Sm}=$ smallholder-based model).

\begin{tabular}{|c|c|c|c|c|c|c|c|c|c|}
\hline \multirow[t]{4}{*}{ Change in variable } & \multirow{2}{*}{$\begin{array}{c}\text { Scenarios } \\
\text { Business models }\end{array}$} & \multicolumn{2}{|c|}{ NPV [M\$] } & \multicolumn{2}{|c|}{$\operatorname{IRR}[\%]$} & \multicolumn{2}{|c|}{ PBP [yr] } & \multicolumn{2}{|c|}{ Production costs $\left[\$ 1^{-1}\right]$} \\
\hline & & Pl. & Sm. & $\mathrm{Pl}$. & Sm. & $\mathrm{Pl}$. & Sm. & Pl. & Sm. \\
\hline & Semi manual - low capacity & 15 & 8 & 17 & 14 & 13 & 13 & 1.32 & 1.28 \\
\hline & Mechanized - high capacity & -3 & 18 & 7 & 18 & $>20$ & 12 & 1.45 & 1.20 \\
\hline Reduction of $\mathrm{CO}_{2}$ revenue from US\$ & Semi manual - low capacity & 11 & 4 & 15 & 11 & 14 & 16 & Same & \\
\hline $350,000 \mathrm{yr}^{-1}$ to US $\$ 0$ & Mechanized - high capacity & -7 & 14 & 5 & 16 & $>20$ & 13 & & \\
\hline Unchanged SVO price at US\$ & Semi manual - low capacity & 49 & 35 & 26 & 23 & 11 & 11 & 1.28 & 1.35 \\
\hline $\begin{array}{l}2,000 \$ \text { ton }^{-1}, \text { instead of decrease } \\
\text { over time to US } \$ 1,000 \$ \text { ton }^{-1}\end{array}$ & Mechanized - high capacity & 32 & 68 & 19 & 27 & 14 & 11 & 1.41 & 1.31 \\
\hline Increase in discount rate from $8.2 \%$ & Semi manual - low capacity & 2 & -1 & 17 & 14 & 16 & $>20$ & Same & \\
\hline to $15 \%$ & Mechanized - high capacity & -9 & 3 & 7 & 18 & $>20$ & 16 & & \\
\hline Increase in seed purchase price & Low capacity & & 2 & & 10 & & 16 & & 1.38 \\
\hline $\begin{array}{l}\text { from smallholders from US\$0.16 } \\
\text { to US } \$ 0.20 \mathrm{~kg}^{-1}\end{array}$ & High capacity & & 8 & & 13 & & 14 & & 1.30 \\
\hline Yield increase in the semi-manual & 2 ton $/ \mathrm{ha}^{-1} / \mathrm{yr}^{-1}$ & 41 & & 22 & & 11 & & 1.13 & \\
\hline plantation system from 1.1 to 2,4 & 4 ton $\mathrm{ha}^{-1} \mathrm{yr}^{-1}$ & 98 & & 26 & & 10 & & 1.06 & \\
\hline and 6 ton $\mathrm{ha}^{-1} \mathrm{yr}^{-1}$ & 6 ton $\mathrm{ha}^{-1} \mathrm{yr}^{-1}$ & 155 & & 27 & & 10 & & 1.04 & \\
\hline $\begin{array}{l}\text { Inclusion of wood sales of } 12.7 \mathrm{~m}^{2} \\
\text { of harvestable timber/ha from } \\
\text { original vegetation at plantation. }\end{array}$ & $\begin{array}{l}\text { US } \$ 61.70 \text { gross margin of timber } \\
\text { sales per cubic meter }\end{array}$ & 42 & & 91 & & 3 & & 0.87 & \\
\hline
\end{tabular}

clearing during the first 11 years of the project (approximately US $\$ 27 \mathrm{~m}$ ) are included. If these revenues are deducted from the costs of production, the cost per litre SVO falls spectacularly from US\$1.32 to US\$ 0.87. However, this scenario is not informative about the profitability of jatropha cultivation as such.

The results discussed above still include uncertain benefits from carbon credits. Voluntary Credits (VCAs) are being traded at other jatropha plantations, but their price can sink to a low US\$ 2-3 per ton. Therefore, in the sensitivity analysis (Table 4), the effect on profitability of the removal of the $\mathrm{CO}_{2}$ credits has been assessed. The sensitivity analysis also assesses effects from variations in seed yield and the oil sales price, as these are also uncertain.

Profitability is apparently sensitive to the SVO price. In the original estimation, that price is assumed to decrease over time from US\$ 2000 to US\$ 1000 per ton. This was assumed because the market for jatropha oil is still immature, with limited supply in relation to demand. One might expect the price to decrease over time to a competitive level comparable to fossil diesel (of around US\$ 0.80-1.00 $1^{-1}$ [43]). If the SVO price was to remain at US\$ 2000 ton $^{-1}\left(\approx 1.91 \$ 1^{-1}\right)$ until 2025, the projects' financial prospects would be substantially better. In practice, the SVO price will depend closely on the fossil fuel price. If the latter rises over time due to structural high demand on world oil markets, the SVO price may remain well above US\$ 1000 per ton.

An increase in the purchase price of seeds from the smallholders and an increased discount rate have smaller influences on profitability. An improved yield per ha would have major positive effects on the plantation project, but this might only be possible against higher input costs (these effects not assessed here).

\subsection{Local prosperity}

All general background prosperity indicators considered for this study indicate that Tanzanian material living standards are extremely low. A large proportion of the population live below the international and national poverty lines: $97 \%$ earns less than US\$2 PPP (2000-'07), 68\% is below US\$ 1.25 PPP (2000-'09) and $33 \%$ is below the national poverty line (2000-'09). Average income in 2009 was a mere US\$ 548 per capita. Just $55 \%$ of households own a radio, a mere $2.0 \%$ own a mobile phone, $5.8 \%$ a wheelbarrow, $43 \%$ a bicycle, and $1.1 \%$ a TV [73]. There are also notable differences in poverty between regions and groups $\left(\mathrm{GINI}_{2011}=37.6\right)$, which means that some regions and groups are even worse off; see Appendix B for more poverty statistics.

The impacts on local prosperity by the smallholder system and plantation system are detailed in Table 5.

Especially given the extreme poverty in rural Tanzania, the overall impact on local prosperity can be considered quite positive for both models. They both generate employment and income. The plantation generates higher profits per beneficiary, while the smallholder system has many more beneficiaries but generates lower revenues per person. All wages are above the minimum salary range set by the Tanzanian Government (US\$ 49-245 2010 [79]). The salary scales for higher skilled labour in the two companies are comparable. In the smallholder system the occurrence of middlemen is an issue, since they could pay seed sellers below the minimum price set by the processor. This has occurred a few times in practice. On the other hand, higher than factory gate prices also have been paid in times of high seed demand.

The plantation company offers more investments in education and health facilities, while the farmers in the smallholder model receive more training, and the use of local transport stimulates local entrepreneurs. In a fully manual harvesting regime, employment requirements at the plantation would exceed available employment in the region which would cause migration of people, this could be a threat to both food and water supplies in the region.

Both models also affect the local economy by purchasing tools and materials locally. Not all the expenditures are local, 
Table 5 - Comparison of local prosperity effects of the two business models.

\begin{tabular}{|c|c|c|c|}
\hline $\begin{array}{l}\text { Local prosperity } \\
\text { Comparison }\end{array}$ & Indicator & Smallholder-based model & Plantation model \\
\hline \multirow[t]{2}{*}{$\begin{array}{l}\text { Wages and } \\
\text { employment }\end{array}$} & Employment & $\begin{array}{l}126 \text { field officers, and part time } \\
\text { occupation for } 80,000-160,000 \text { self- } \\
\text { employed farmers }\end{array}$ & $\begin{array}{l}81 \text { field officers and } 10,000-35,000 \\
\text { employees, mostly low skilled for } \\
\text { harvesting, see Ref. [72]; } 6000 \\
\text { employees if harvesting is fully } \\
\text { mechanized }^{\text {a }} \text {. }\end{array}$ \\
\hline & Wages & $\begin{array}{l}\text { Above minimum wage for } \\
\text { employees; Farmer seed sales } \\
\text { revenue: US } \$ 70-140 / \text { year, based } \\
\text { on US\$ 0.14/ } / \mathrm{kg}^{\mathrm{b}} \text {. Occurrence of } \\
\text { middlemen and low seed } \\
\text { payments are issues }\end{array}$ & Above minimum wage \\
\hline \multirow{5}{*}{$\begin{array}{l}\text { Impact on local } \\
\text { economy }\end{array}$} & Total investment costs & US\$ $11 \mathrm{~m}$ & US\$ $32 \mathrm{~m}$ \\
\hline & Total costs (discounted) (20 yrs) & $\begin{array}{l}\text { US } \$ 77-130 \mathrm{~m} \text { (US\$ } 33-59 \text { is spent } \\
\text { on purchasing seeds from farmers } \\
\text { and US\$ } 4.8 \mathrm{~m} \text { on transport within } \\
\text { region) }\end{array}$ & US\$ $107-125 \mathrm{~m}$ \\
\hline & Education and health investments & $\begin{array}{l}\text { No foundation established yet, but } \\
\text { plans exist }\end{array}$ & $\begin{array}{l}\text { Through foundation: maternity } \\
\text { ward, classrooms, vegetable } \\
\text { garden. With land acquisition } \\
\text { money: classrooms, tractor, see } \\
\text { Ref. [75] }\end{array}$ \\
\hline & Local purchases & $\begin{array}{l}\text { Large complex equipment } \\
\text { imported, all else purchased locally }\end{array}$ & $\begin{array}{l}\text { Small equipment, tools and } \\
\text { stationery purchased locally or } \\
\text { elsewhere in Tanzania, all large } \\
\text { equipment imported }\end{array}$ \\
\hline & $\%$ of costs related to processing & $11 \%$ & $18-20 \%$ \\
\hline Origin of employees & $\begin{array}{l}\text { Management functions by local } \\
\text { population }\end{array}$ & $\begin{array}{l}1 \text { out of } 4 \text { management positions } \\
\text { fulfilled by expats, foreign } \\
\text { shareholders }\end{array}$ & $\begin{array}{l}\text { Unskilled from the region, skilled } \\
\text { from outside, } 7 \text { out of } 18 \\
\text { management positions fulfilled by } \\
\text { expats, foreign shareholders }\end{array}$ \\
\hline \multirow[t]{2}{*}{ Social wellbeing } & $\begin{array}{l}\text { Perceptions about project, incl. } \\
\text { perception of risk when project } \\
\text { would be abandoned }\end{array}$ & $\begin{array}{l}\text { Extension service to farmers and } \\
\text { facilitation of credit access fosters } \\
\text { farmers' perceptions of increased } \\
\text { wellbeing and trust; see Ref. [76]. } \\
\text { Skepticism possible if project } \\
\text { would be abandoned }\end{array}$ & $\begin{array}{l}\text { Not studied. Increased income } \\
\text { might lead to increased social } \\
\text { wellbeing, but high levels of } \\
\text { skepticism/anger if project is } \\
\text { abandoned }\end{array}$ \\
\hline & Impact if project fails & $\begin{array}{l}\text { Possible to take up 'old lives' again, } \\
\text { little change in daily routine }\end{array}$ & $\begin{array}{l}\text { Difficult/impossible to go back to } \\
\text { 'old lives', major disruption }\end{array}$ \\
\hline
\end{tabular}

${ }^{a}$ Fully mechanized harvest requires around 180 harvesters with 3 workers per harvester, so around 540 workers instead of 24,400 if 88,000 tons of seed production is harvested with an efficiency of $40 \mathrm{~kg}^{\text {person }}{ }^{-1}$ day $^{-1}$ [74] for 90 days per year.

b If the price of seeds is $0.14 \$ \mathrm{~kg}^{-1}$, a total amount of $15 \mathrm{~kg}$ would have to be collected daily to earn on the poverty line of $2 \$$ day ${ }^{-1}$. An average is $40 \mathrm{~kg} \mathrm{day}^{-1}$ [74], so this seems achievable for around 25 days per year even without other income.

c This actually happened in 2010, when the Dutch holding of BioShape went bankrupt, and all activities in Tanzania stopped, included the activities of the social benefits foundation, see Ref. [78,83].

however. Salaries of non-Tanzanians will (partly) end up abroad, furthermore, since both companies have Dutch holdings it is very likely that the profits after tax deductions will (partly) go abroad as well. All advanced equipment is imported from other countries due to sheer unavailability in Tanzania. The location of processing would have a major influence on the occurrence of local spin-off effects; originally the plantation company wanted to process the seeds abroad, this would mean low capacity building and value added creation inside Tanzania.

Perhaps the greatest risk for social wellbeing emanating from the projects arises from the risk of project failure. This could induce high scepticism in the local population due to unkept promises [78]. In the plantation model, the entirely basis of people's livelihoods would also be disrupted; it might not be easy or even possible to revert back to prior livelihoods based on subsistence farming. In comparison, disruptions to livelihoods of the outgrowers in the smallholder model would be much less drastic as jatropha hedge cultivation is an incremental activity for farmers with low risks.

\subsection{Labour and working conditions}

Child labour is common in Tanzania, although prohibited under Tanzanian law. The 2002 Population and Housing Census classifies almost $40 \%$ of 9 million children in Tanzania as economically active for most of the twelve months prior to the census reference month. Among those, $16 \%$ were classified as doing unpaid work, $12 \%$ as working for own benefit and 
$12 \%$ as doing paid work. Even among children aged 5-9 years old, $29 \%$ were classified as economically active, of which $40 \%$ (363,000 children) on usual status [80].

Neither at the plantation nor at the processor was any child labour observed; worker age was verified by checking IDcards. In the smallholder system children do usually help with household and agricultural tasks, as is common in lowincome rural societies, and observed by Mitchell [81], but the money earned by selling seeds is sometimes used for school fees. Helping with farm work does not imply that children do not attend school. All Diligent's outgrowers state that their children attend school regularly. This is in fact a condition for production on contract. But it is more difficult to detect and prevent excessive and exploitative child labour in a smallholder system than in a plantation system. Table 6 gives a full comparison of labour and working conditions.

Risks arising from possible project failure loom large in the plantation model. In fact, major problems have arisen here in reality. After the bankruptcy of the Dutch BioShape Holding in April 2010, all 400 daily workers were suddenly sent home, while the contract workers were kept on for six more months, for which they were never paid. Despite the existence of national regulations to prevent these situations, no employment stability or social security was observed. A law suit has been filed in Dar es Salaam High Court trying to retrieve the unpaid salaries of over 90 contract workers $[83,84]$. Failure of the processor company in the smallholder system would have more limited effects. The workers in the factory and the field team would stop receiving benefits and the smallholders would lose their market for seeds, although other seed buyers/processors may fill that gap in some regions. The impact of market loss on total household income would be minor.

In sum, both systems formally have similar labour and working conditions (although it is difficult to verify the conditions in smallholder households), but there are large differences in the set-up and the manner of implementation of the two systems, which affect how things work out on the ground. The processor firm in the smallholder system places considerable emphasis on providing employee skill training, more so than the plantation. Perhaps the latter could have organized this under the wing of its foundation, but it never reached this stage due to its bankruptcy.

Many issues discussed above - poverty, wages and employment, prices and rural development, also have a close relationship with the next topic of food security.

\subsection{Food security}

\subsubsection{Background information}

In Tanzania roughly $15 \%$ of households are considered food insecure, with a similar proportion considered highly vulnerable [51]. Regional variability in food insecurity varies between $5 \%$ to above $50 \%$ of households (see Appendix C in the online supplementary material), but all regions suffer from high rates of stunting among children under five, indicative of chronically low nutrient intake. Thus, food security is a concern in all regions. Households relying mainly on small

Table 6 - Labour and working conditions in the two business models.

Smallholder-based model

\begin{tabular}{|c|c|}
\hline Legal issues & $\begin{array}{l}\text { Obeying all relevant ILO and } \\
\text { national regulations }\end{array}$ \\
\hline $\begin{array}{l}\text { Child labour provisions (children in } \\
\text { employment and hazardous work) }\end{array}$ & $\begin{array}{l}\text { None employed (farmers might ask } \\
\text { their children to help) }\end{array}$ \\
\hline Discrimination & $\begin{array}{l}\text { Fieldofficers from all tribes, } \\
\text { substantial number of female } \\
\text { employees }\end{array}$ \\
\hline Forced and compulsory labour & None \\
\hline Disciplinary practices & Warning system before dismissing \\
\hline Safety & $\begin{array}{l}\text { Protective wear provided to factory } \\
\text { employees }\end{array}$ \\
\hline Freedom of trade union organization & $\begin{array}{l}\text { Freedom of association/right to } \\
\text { organize; contacts with labour } \\
\text { unions }\end{array}$ \\
\hline Education/training & $\begin{array}{l}\text { Courses provided depending on } \\
\text { skills (computer, human resource, } \\
\text { also HIV/AIDS) }\end{array}$ \\
\hline Working hours & $\begin{array}{l}\text { Normally } 5.5 \text { days a week, over } \\
\text { time is paid } 150 \% \text { or } 200 \% \text { (Sunday). } \\
\text { Over time and night shifts do occur } \\
\text { occasionally }\end{array}$ \\
\hline Secondary benefits & $\begin{array}{l}\text { Provision of meals } \\
\text { Coverage of medical cost } \\
\text { Provision of education for } 1 \text { child } \\
\text { per employee }\end{array}$ \\
\hline
\end{tabular}

Plantation model

Obeying all relevant ILO and national regulations, however, very poor exit strategy (lawsuits ongoing), contravening article 26 of ILO None employed

Based on skills and talent, not on tribe or gender, although preference is given to local people

None

Warning system before dismissing (in practice not always applied)

Safety regulations (but unclear and no processing took place yet)

Freedom of association/right to organize; contacts with labour unions

No specific training programme but training on the job

No working allowed before 7:00 and after 17:00 (danger of wildlife encounters). Possible exception: work performed on the camp site and at office

Provision of meals

Coverage of medical cost

Provision of housing for staff outside the area

The indicators are based on Refs. [29,40-42,47], see Methodology section. Sources: fieldwork, company business plans [72,82]. 
farming and wage labour are more likely to be food insecure than skilled labourers and traders [51]. Chronic malnutrition is common, affecting over $30 \%$ of children under 5 [51]. Acute malnutrition, which is indicative of recent or current food shocks, is less prevalent with fewer than $6 \%$ of children affected nationwide in 2006, although 10-14\% in some districts affected by drought at that time [51].

National food production figures show a change in food production from 2007 to 2009: millet, maize and cassava production decreased, while rice, wheat flour, beans, banana and sweet potato production increased [80]. The reason for this decline however, is not biofuel production but 'unfavourable weather' [80]. The food price index increased every year since 2001 , but only marginally when compared to the overall price index which also increased [80].

In any business model, food security may increase if household incomes increase [85]. A study of more than 100 smallholders observed that those connected to the jatropha seeds processor reported higher levels of food security and lower incidences of food shortages compared to other smallholders, but the exact reasons could not be verified [76]. A FAO study indicates that smallholder-based biofuel systems are most effective in increasing household income [85]. It indicates that the key factor to increase food security is to increase agricultural yields [85]. Biofuel investments could catalyse this if they invest in increasing local communities' knowledge to achieve this. In our study, the plantation company's efforts in this respect were limited to encouragement of a school garden through its foundation. The processor was making good efforts with agricultural extension services. However, increased public spending will be also necessary to increase access to knowledge, fertilizer, improved seeds and water, and reduce input prices [85].

\subsubsection{Availability and access}

The area targeted for jatropha production by the plantation was not actively in use for crop production or grazing, so food availability was not directly affected. However, communities used it for hunting and possibly firewood gathering, charcoal making, medicinal plant gathering etc. If community members are paid for the reduced access caused by the plantation, then they can compensate for the loss of those resources; however there is evidence that in some cases compensation has not reached affected individuals (Section 3.5). Wage income - if stable - could compensate for the loss of traditional food access. The wages per household (especially for females) should be higher than the market value of the food produced on household plots. However, after the discontinuation of the plantation in 2010, no wages have been paid while land access is still restricted. A report by a Tanzanian NGO [75] also indicated that the production of food in Kilwa decreased during the time that the company was active. This might be due to employees' time reduction for household food plot cultivation. The company did try to limit food price increases by buying the staple food for employees (maize and beans) in the main city Dar es Salaam.

In the smallholder hedge model, food availability and access to resources are not directly affected. A potential knowledge benefit arises from the agricultural extension work, which could help increase food crop yields. However, the timing of initial weeding requirements of jatropha can conflict with those of food crops [81]. Seed harvesting seems to cause fewer conflicts on labour demand.

\subsubsection{Stability}

Sudden one-off shocks are unlikely to be caused by biofuel operations, except when they fail. However, in the plantation model seasonal (harvesting) shocks may occur, particularly as a result of the influx of seasonal job-seekers, self-employed service providers and dependents. For an estimated 10,000 employees, this could involve 50,000 people $[72,86]$, whereas the current population of the five communities providing land to the plantation is less than 7000. The company acknowledged that food demand will be monitored and "food supply will have to increase to service the influx" [[72] p. 45], and that it will establish "farms to service this need" [[72] p. 45], but nothing concrete was planned. A Strategic Impact Assessment noted that the company needs to strengthen monitoring systems. Therefore, the establishment of a large plantation in a sparsely populated region in which $30 \%$ of the population is classified as either "food insecure" or "highly vulnerable" to insecurity is likely to induce instability in supply (due to sudden large in-migration) and poses risks to food security. In contrast, schemes such as Diligent's outgrower model rely primarily on family labour and involve little, if any seasonal labour movement.

\subsubsection{Utilization}

The plantation system was meant to replace 80,000 ha of forest and woodland (map in Appendix E), so ensuring fuel supplies for cooking would become a major issue for the nearby communities and seasonal migrants. Yet, the company business contains no plan to ensure adequate fuel supplies, so food security also could be threatened through lack of access to cooking fuel. Such threats are unlikely to arise in the smallholder production system. Smallholders were never observed to replace live fences containing fuelwood species entirely with jatropha. The processor also produced seedcakebased alternatives for charcoal and wood for use in urban areas: solid fuel briquettes, pellets and biogas from the seedcake [74,87]. In contrast, the initial plantation model foresaw $100 \%$ oil extraction in Europe, with the seedcake to be utilized as a solid fuel in European power plants [72]. It remained unclear how the seedcake would be used if domestic processing were to occur after all, likely as fertilizer for the jatropha field.

Finally, local food security can be increased by improved (road) infrastructure, by making regions more accessible and cheapening transport to and from there (see Appendix C for major recent infrastructure improvements effected in Tanzania). However, neither company contributed to improved local infrastructure. BioShape's initial plans to upgrade Kilwa harbour were only meant for seed export (but those plans did not materialize).

In sum, food security can be affected in many ways in both business models (see Table 7 for a compilation of all factors discussed above), but risks are likely to be much greater in the plantation model due to the high influx of labourers. However, there are various measures that can be taken to prevent 
Table 7 - Comparison of the food security impact by the two business models.

Smallholder-based model

\begin{tabular}{|c|c|c|}
\hline $\begin{array}{l}\text { Food availability and access } \\
\text { (production in region) }\end{array}$ & Not affected, but labour competition can arise ${ }^{a}$ & $\begin{array}{l}\text { Decreased but could be compensated by } \\
\text { wages and compensation money. Effect } \\
\text { on local food prices unclearb. } \\
\text { Compensation for loss of resources might } \\
\text { not reach targeted group }\end{array}$ \\
\hline Food stability & No impact & $\begin{array}{l}\text { Large influx of employees and job seekers } \\
\text { might affect }\end{array}$ \\
\hline Utilization & No impact & $\begin{array}{l}\text { Possible loss of wood resourced is threat to } \\
\text { cooking fuel provision }\end{array}$ \\
\hline \multirow[t]{2}{*}{ Measures to increase food security } & Increase income & Increase income \\
\hline & $\begin{array}{l}\text { Extension services to increase food production } \\
\text { Jatropha co-products used as } \\
\text { energy source (biogas, solid fuel briquettes or pellets) }\end{array}$ & Revitalize harbour (not executed) \\
\hline
\end{tabular}

adverse effects or even improve the food security situation. For example, the management can regulate working hours so that some daytime is left for workers to cultivate their own food plots too. It can also prioritize food production on part of the plantation itself. Initial labour (weeding) constraints in a smallholder system are in any case limited to $2-3$ years, but farmers should also be advised to keep prioritizing food production.

\subsection{Land rights}

More land titles were issued and more village land certificates were handed out in Tanzania in 2009 compared to 2008 but there are also more disputes reported. However, most disputes involve areas close to cities like Dar es Salaam and Mwanza rather than truly rural areas, were our companies operated [80]. See Appendix D for details about land issues.

\subsubsection{Plantation}

At the time of study, BioShape had acquired the first 34,000 ha of the planned ultimate 81,000 ha. This was previous "village land" that had been transferred into central governmentowned "general land" [3,56] for the purpose of enabling a foreign investor to lease it. However, BioShape did not acquire the lease through the official route, namely the Tanzanian Investment Centre, but rather through the "services" of employees in another ministry [88]. When this fact came out, it was not good for the company's reputation within Tanzania. The minister in question was later removed from office in connection with corruption.

According to one field study involving one of the involved villages [3] the village still had spare land left, such as settlement areas and Village Land Forest Reserves. The local communities were also satisfied with the company's approach, although they also mentioned that in one village compensation money had not been received - possibly due to a conflict between village and district council over the division of the compensation money [3].

The total amount of money that was paid varies in different sources from US\$20-30 ha $\mathrm{ha}^{-1}$ or US\$ $0.5-1 \mathrm{~m}$ for
34,000 ha $[86,89]$. The money was paid through the district authorities, which kept part of it to allegedly support the development of social services in villages in the district [3]. This was something that the village authorities had not counted on, and its legitimacy was questioned by them. It is also unclear whether the remaining share of the money that was destined for the village communities, has been distributed by the village councils to the actual villagers. Since BioShape went bankrupt it is also unclear whether villagers will ever regain their land rights, as there is no legal precedent of turning general land back into village land. Villagers surrounding another jatropha company that went bankrupt in Tanzania are facing the same issue [78].

\subsubsection{Smallholders}

In a smallholder-based model, land issues are less prominent because no land ownership transfers take place [56]. In principle, farmers decide whether or not they want to plant jatropha and/or stop cultivating other crops on their own land. However, vulnerable groups can be affected. An additional use for land like this can worsen already existing pressures on the land, and can thus bring latent conflicts to the surface. Landowners for example, sometimes oppose to the planting of jatropha because they fear their tenants will then claim more permanent tenure rights [90], an issue observed between the pastoralist Masaai tribe and Arusha airport authority. However, with the majority of the smallholders associated with the smallholder company no conflicts were found. Rather, a positive effect from jatropha was noted in the form of resolution of land conflicts. In some regions in Tanzania it was observed that farmers liked to plant jatropha as a fence because it limited conflicts with neighbours. This was also observed in Mali [19]. One qualification to make is that the regions in which the smallholder company is active are familiar with jatropha cultivation and the plants have been used as fences since decades. In other locations this might be different. Hence, it could take longer to learn to cultivate it, or that lives would change more significantly than in our case study.

Table 8 summarizes the land rights impacts from the two business models. 
Table 8 - Summary of impacts of the two companies on land rights.

Smallholder

Land acquisition procurement, change in land access

Amount of ha land transfer

Compensation for reduction

Displacement of people

Transparency of the process

N.A.

N.A.

Potential risk in case of project failure

Low, hedgerows will not gain income but other production just continues.

Public opinion

Good, no land right changes involved. Some increased and lowered conflicts on land boundaries.

or impacts, weaker groups could have difficulties. Expanding into prior uncultivated land can be an issue. 0 ha

N.A.
Plantation

Village land transferred into general land and after this transferred to the company. Villages have lost access and legal rights to (part of) their land. ${ }^{\mathrm{b}, \mathrm{c}}$ 34,500 ha $^{\text {b.c }}$

Around $30 \$ \mathrm{ha}^{-1}$ for local authorities and villagers, conflicts on commercial value and division of money. ${ }^{\mathrm{d}}$

13 people

Unclear, it is not clear whether stakeholders consultations have taken place, also unknown whether documentation was made available in Swahili.

High, land rights are transferred to central government, no clause in contract that land is returned to villagers if company fails. ${ }^{f}$

Medium, foreign companies are seen as 'land grabbers' by some, but others are keen to see development in their area because they think they can profit.

\footnotetext{
${ }^{a}$ When land tenure systems are weak, the rural population might experience difficulties sustaining their land access [7,19]. Furthermore, Wahl et al. [91] observed that only a few smallholders hold official land ownership certificates in Northern Tanzania. Mitchell [81] indicated that more than $93 \%$ of the 74 jatropha outgrowers she interviewed perceived expanding their land, for multiple reasons, as problematic. Wahl et al. [91] observed in the same region that $76-86 \%$ of the households use their maximum amount of land for agricultural production, this was based on the National Sample Census of Agriculture 2002/2003.

b Ref. [3].

c Ref. [56].

d The company paid around 30 \$ per hectare as a compensation payment, which is a total of $2.76 \mathrm{M} \$$ (for 92,500 ha) and of these revenues $40 \%$ went to the district government, $30 \%$ to the village and $30 \%$ to the central government [86]. Other sources mention other figures, such as 676,000 $\$$ for 34,000 ha [89].

e This is mentioned in [92], however no further information was revealed.

${ }^{\mathrm{f}}$ A report by a Tanzanian NGO mentions several unsatisfied villagers, mainly after the company had stopped operations early 2010 [75].
}

It is clear that land rights are much more impacted by the plantation model than by the smallholder model. Unrelated to bioenergy production as such are the procedures to acquire land, determine its value, and ensure that villagers get adequate compensation, all of which are quite unclear.

\subsection{GHG balance}

A significant correlation was found between the NDVI values and the aboveground carbon content samples $(p<0.001)$, linear regression explained $51 \%$. The most common vegetation type is forest ( $39 \mathrm{tC} \mathrm{ha}^{-1}$ ) while the second most common type is open forest (11 tC ha-1), see Fig. 3 .

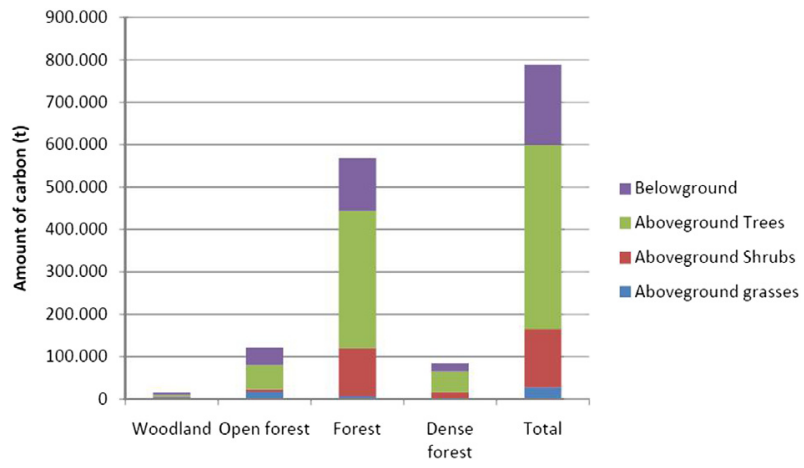

Fig. 3 - The total above and belowground carbon $(t)$ in the plantation area per vegetation type.
Woodland ( $\left.5 \mathrm{tC} \mathrm{ha}^{-1}\right)$ and dense forest $\left(44 \mathrm{tC} \mathrm{ha}^{-1}\right)$ are less common. The total carbon stock in the area is estimated at $788,700 \mathrm{tC}$ or on average $25.6 \mathrm{tC} \mathrm{ha}{ }^{-1}$. A carbon map of the plantation area is in Appendix E (App. Fig. 5).

The carbon content of the soil (SOC) is estimated to vary between 31 and 40 tC ha ${ }^{-1}$ (values derived from existing studies; details in Appendix E) [93,94]. The carbon storage in jatropha plantations depends a lot on the pruning regime, and is estimated to be $13 \mathrm{tC} \mathrm{ha}{ }^{-1}[94,95]$ which also tallies with the average of the range of $8-17.5 \mathrm{tC} \mathrm{ha}^{-1}$ reported by other studies $[96,97]$. It is assumed that jatropha planted as hedgerows in the smallholders system hardly replaces other land uses.

See Table 9 for a comparison of all estimated emissions in the two business models.

The largest contributing factors to the GHG balance by far are the removal of the original vegetation $(-)$ and the carbon sequestration in the jatropha $(+)$. All other factors only have a marginal influence. The smallholder model generates highly favourable GHG results (151\% reduction), whereas the plantation model only approximates carbon neutrality ( $2 \%$ reduction) over a 20-year period. If an economic allocation method instead of one based on energy would be used (in which $92 \%$ of emissions would be allocated to the SVO, instead of $42 \%$ ) the emission reduction would decrease to $-114 \%$ (so an increase) for the plantation model and a further reduction to more than $200 \%$ in the smallholder model. The uncertainties are very large, but the smallholder model definitely performs much better than the plantation model. 
Table 9 - GHG balance for jatropha oil from plantation (semi manual harvesting) including upper and lower ranges and smallholders (low capacity scenario). Depreciation period is 20 years.

\begin{tabular}{|c|c|c|}
\hline Emission component & $\begin{array}{c}\text { Smallholders }^{\mathrm{a}} \\
\text { emissions }\left(\mathrm{kg} \mathrm{CO}_{2^{-}}\right. \\
\left.\text {eq } \mathrm{ha}^{-1} \mathrm{yr}^{-1}\right)\end{array}$ & $\begin{array}{l}\text { Plantation }{ }^{\mathrm{b}} \text { emissions } \\
\left(\mathrm{kg} \mathrm{CO}_{2} \text {-eq } \mathrm{ha}^{-1} \mathrm{yr}^{-1}\right)\end{array}$ \\
\hline
\end{tabular}

Most positive estimate plantation emissions (kg CO -eq $\mathrm{ha}^{-1} \mathrm{yr}^{-1}$ )
Most negative estimate plantation emissions

\begin{tabular}{|c|c|c|c|c|}
\hline $\begin{array}{l}\text { (A) Removal of original } \\
\text { vegetation }\end{array}$ & 0 & $4,533^{\mathrm{C}}$ & $3,562^{d}$ & $4,569^{e}$ \\
\hline \multicolumn{5}{|l|}{ (B) Jatropha growth: } \\
\hline Carbon stock jatropha & $-1283^{f}$ & $-2383^{g}$ & $-3208^{h}$ & $-1467^{i}$ \\
\hline$\Delta$ Carbon stock soil $^{j}$ & 0 & $-293^{k}$ & 0 & $-293^{k}$ \\
\hline Fertilizer use $\left(\mathrm{N}_{2} \mathrm{O}\right)$ & 142 & $604^{1}$ & $142^{\mathrm{m}}$ & $604^{\mathrm{n}}$ \\
\hline $\begin{array}{l}\text { Use of agricultural } \\
\text { machinery }\end{array}$ & 0 & $434^{\circ}$ & $159^{p}$ & $488^{9}$ \\
\hline $\begin{array}{l}\mathrm{CO}_{2}, \mathrm{~N}_{2} \mathrm{O}, \mathrm{CH}_{4} \text { indirect } \\
\quad \text { (fertilizer production) }\end{array}$ & 178 & $259^{r}$ & $178^{s}$ & $1365^{\mathrm{t}}$ \\
\hline $\begin{array}{l}\text { (B) Jatropha growth } \\
\text { (total) }\end{array}$ & -963 & -1379 & -2729 & 1283 \\
\hline Land use change $(\mathrm{A}+\mathrm{B})$ & -963 & 3154 & 833 & 5852 \\
\hline Transport & $26^{t}$ & $186^{\mathrm{u}}$ & $26^{t}$ & $186^{\vee}$ \\
\hline Conversion & $16^{\mathrm{w}}$ & $31^{x}$ & $16^{\mathrm{w}}$ & $31^{x}$ \\
\hline Transport to end user & 0 & 0 & & \\
\hline $\begin{array}{l}\text { Allocation to oil } \\
\text { (excluding residues } \\
\text { and co-products) [\%] }{ }^{\mathrm{y}}\end{array}$ & 42 & 42 & 42 & 42 \\
\hline Total & -387 & 1416 & 367 & 2549 \\
\hline Reference fossil fuel & $753^{z}$ & $1448^{\mathrm{aa}}$ & 753 & 1448 \\
\hline Emission reduction (\%) & $151 \%$ & $2 \%$ & $51 \%$ & $-76 \%$ \\
\hline
\end{tabular}

${ }^{\text {a }}$ Hedgerow planting, no removal of original vegetation, no use of machinery, yield of 1 ton $\mathrm{ha}^{-1} \mathrm{yr}^{-1}$, depreciation period $20 \mathrm{yr}$.

b Semi manual harvesting, yield 2 tons $\mathrm{ha}^{-1} \mathrm{yr}^{-1}$, depreciation period $20 \mathrm{yr}$.

c Carbon stock $25.6 \mathrm{tC}$ ha ${ }^{-1}$ (based on field measurements), in formula: carbon stock times $\mathrm{CO}_{2} / \mathrm{C}$-molar mass ratio (44/12) divided by the depreciation period is $4693 \mathrm{CO}_{2}$-eq. In addition emissions from burning biomass and from the use of land clearing machines are estimated to be 96-131 and a reduction of $256 \mathrm{~kg} \mathrm{CO}_{2}$-eq ha ${ }^{-1} \mathrm{yr}^{-1}$ is applied due to the decrease of forest fires and denitrification. No useful application of the vegetation is assumed.

d Useful application of the vegetation (furniture), therefore only $33 \%$ of the emissions are allocated to jatropha instead of $42 \%$, here the value for $100 \%$ is depicted.

e The highest range ( $44 \mathrm{~kg} \mathrm{CO}_{2}$-eq ha $\mathrm{hr}^{-1} \mathrm{yr}^{-1}$ ) for emissions from land clearing machines is used [98].

f Carbon stock jatropha $7 \mathrm{tC} \mathrm{ha}{ }^{-1}$ [99], depreciation period $20 \mathrm{yr}$, based on hedges grown in Tanzania with $40 \mathrm{~cm}$ spacing, the same formula as c.

$\mathrm{g}$ Carbon stock jatropha $13 \mathrm{tC} \mathrm{ha}^{-1}$ based on belowground 8-10 tC ha ${ }^{-1}$ [94] and the same root/shoot ratio as [95] which leads to 11-14 tC ha ${ }^{-1}$ averaged as $13 \mathrm{tC} \mathrm{ha}^{-1}$, depreciation period $20 \mathrm{yr}$, the same formula as c.

h Carbon stock jatropha $17.5 \mathrm{tC} \mathrm{ha}{ }^{-1}$ [97], depreciation period $20 \mathrm{yr}$, the same formula as c.

${ }^{\mathrm{i}}$ Carbon stock jatropha $8 \mathrm{tC} \mathrm{ha}^{-1}$, depreciation period $20 \mathrm{yr}$, the same formula as c. This is an average of 7.8 tC ha ${ }^{-1}$ according to [96] and $8.1 \mathrm{tC} \mathrm{ha}^{-1}$ according to [100].

$j$ Ryan et al. [105] have calculated the amount of carbon in the soil of miombo woodland in Mozambique, and found the values varying from 32 to $133 \mathrm{tC} \mathrm{ha}^{-1}$. Depending on the severeness of depletion, the study by Romijn [118] uses a range of 49-81 tC ha ${ }^{-1}$ for African miombo woodland. The conversion from Caatinga woodland to jatropha (rather similar to miombo to jatropha) is estimated as 29 tC ha ${ }^{-1}$ by [94] while a reduction due to the clearing of the biomass was estimated as $24 \mathrm{tC} \mathrm{ha}^{-1}$ by the same study. The high values for clearing original vegetation are furthermore confirmed by Achten [95], who estimated the effect of removal of original vegetation from tropical savannah to forest between 24 and $118 \mathrm{tC} \mathrm{ha}^{-1}$.

$\mathrm{k}$ Based on BioShape estimate of $1.6 \mathrm{tC} \mathrm{ha}^{-1}$ carbon storage, fruits are left on the field, the same formula as c.

${ }^{1} 6.4 \mathrm{~kg} \mathrm{~N}_{2} \mathrm{O} \mathrm{ha}^{-1} \mathrm{yr}^{-1}, \mathrm{~N}_{2} \mathrm{O}$ is 296 times stronger than $\mathrm{CO}_{2}$, it is assumed that fruit hulls are brought back to the plantation area.

$\mathrm{m}$ [101], emission factor $0.01 \mathrm{~kg} \mathrm{~N}_{2} \mathrm{O} \mathrm{kg} \mathrm{N}^{-1}$ [93] or $2.96 \mathrm{~kg} \mathrm{CO}_{2}$-eq kg N-fertilizer ${ }^{-1}$, application rate [102]; diesel use 55-141 l ha ${ }^{-1} \mathrm{yr}^{-1}$, emissions 159-407 kg CO -eq ha $^{-1} \mathrm{yr}^{-1}$, assumed that preparation of the land is included, emissions between 142.1 and $417.4 \mathrm{~kg} \mathrm{CO}_{2}$-eq ha ${ }^{-1}$.

$\mathrm{n}$ Emission factor $0.01 \mathrm{~kg} \mathrm{~N}_{2} \mathrm{O} \mathrm{kg} \mathrm{N}{ }^{-1}$ [93] or $2.96 \mathrm{~kg} \mathrm{CO}_{2}$-eq $\mathrm{kg} \mathrm{N}^{-f_{e} \text { [ilizer }}{ }^{-1}$, application rate; (BioShape tool); diesel use $150 \mathrm{l} \mathrm{ha}{ }^{-1} \mathrm{yr}^{-1}$, emissions $453-488 \mathrm{~kg} \mathrm{CO}_{2}$-eq ha ${ }^{-1} \mathrm{yr}^{-1}$ of which 9-44 for the preparation of land and 444 for jatropha growth, emissions between $332-604 \mathrm{~kg} \mathrm{CO}_{2}$-eq ha ${ }^{-1}$. ○ Use of machinery for growing jatropha $5419 \mathrm{MJ} \mathrm{ha}^{-1}$ assuming mechanized harvesting, diesel use $150 \mathrm{l} \mathrm{ha}{ }^{-1}$, density of diesel is $0.85 \mathrm{~kg} \mathrm{l}^{-1}$, energy content $42.5 \mathrm{MJ} \mathrm{kg}^{-1}$. Direct and indirect $\mathrm{CO}_{2}$ emissions from diesel use respectively: $0.07-0.01 \mathrm{~kg} \mathrm{CO}_{2}-\mathrm{eq}$ ha ${ }^{-1} \mathrm{yr}^{-1}$.

$\mathrm{p}$ [102]; diesel use 55-141 $1 \mathrm{ha}^{-1} \mathrm{yr}^{-1}$, emissions $159-407 \mathrm{~kg} \mathrm{CO}_{2}$-eq ha ${ }^{-1} \mathrm{yr}^{-1}$, assumed that preparation of the land is included.

$\mathrm{q}$ Diesel use $150 \mathrm{l} \mathrm{ha}^{-1} \mathrm{yr}^{-1}$, emissions $453-488 \mathrm{~kg} \mathrm{CO}_{2}$-eq ha ${ }^{-1} \mathrm{yr}^{-1}$ of which 9-44 for the preparation of land and 444 for jatropha growth.

$\mathrm{r}$ Yield assumed 2 ton $\mathrm{ha}^{-1} \mathrm{yr}^{-1}$, fertilizer need $\mathrm{N}-\mathrm{P}-\mathrm{K}$ : 68-4-12 $\mathrm{kg} \mathrm{ha}^{-1}$, emission factors NPK: 3.7-0.7-0.5.

s [101]; only nitrogen fertilizers, based on nutrient removal between 48-141 kg ha ${ }^{-1}$, emission per kg produced fertilizer are $3.7-6.69 \mathrm{~kg} \mathrm{CO}_{2}-$ eq $\mathrm{kg}^{-1}$ fertilizer using the BioShape tool or Senternovem $\mathrm{CO}_{2}$ tool. [103] respectively, emissions between $178-943 \mathrm{~kg} \mathrm{CO}_{2}$-eq ha ${ }^{-1} \mathrm{yr}^{-1}$.

$\mathrm{t}$ Only nitrogen fertilizers, application rate at plantation is assumed $112-204 \mathrm{~kg} \mathrm{ha}^{-1}$ nitrogen fertilizer, emission per kg produced fertilizer are 3.7-6.7 $\mathrm{kg} \mathrm{CO}_{2}$-eq kg fertilizer ${ }^{-1}$ using the BioShape tool or Senternovem $\mathrm{CO}_{2}$ tool [103] respectively, emissions between $414-1365 \mathrm{~kg} \mathrm{CO}_{2}-$ eq $\mathrm{ha}^{-1} \mathrm{yr}^{-1}$.

u Truck max $10 \mathrm{t}$ within Tanzania, $450 \mathrm{~km}$, seeds are processed in Tanzania, 1 ton seeds per ha, $0.08 \mathrm{~kg} \mathrm{CO}_{2}$-eq $\mathrm{MJ}^{-1}$, truck: $0.73 \mathrm{MJ}$ ton $\mathrm{km}^{-1}$. 
v 2 types of transport, first truck max $35 \mathrm{t}$ within Tanzania $(60 \mathrm{~km})$, and 15,000 t ship to Rotterdam (12,600 km), seeds are processed in

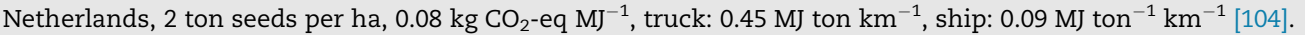

w Conversion efficiency 0.26 ton jatropha oil per hectare, crushing is $36 \mathrm{MJ}$ ton seeds ${ }^{-1}$ (3.8 ton), pressing is $72 \mathrm{MJ}$ ton seedcake ${ }^{-1}$ (2.8 ton) and refining $45 \mathrm{MJ}$ ton oil ${ }^{-1}$ (1 ton), $0.16 \mathrm{~kg} \mathrm{CO}_{2}$-eq $\mathrm{MJ}^{-1}$.

${ }^{x}$ Conversion efficiency 0.5 ton jatropha oil per hectare, crushing is $36 \mathrm{MJ}$ ton seeds ${ }^{-1}$ ( 3.8 ton), pressing is $72 \mathrm{MJ}$ ton seedcake ${ }^{-1}$ ( 2.8 ton) and refining $45 \mathrm{MJ}$ ton oil ${ }^{-1}$ (1 ton), $0.16 \mathrm{~kg} \mathrm{CO}_{2}$-eq $\mathrm{MJ}^{-1}$.

y $42 \%$ allocation to the oil (energy content).

z 0.26 ton oil ha ${ }^{-1} \mathrm{yr}^{-1}, 36.2 \mathrm{GJ} \mathrm{ton}^{-1}, 0.08 \mathrm{~kg} \mathrm{CO}_{2}$-eq $\mathrm{MJ}^{-1}$

aa 0.5 ton oil ha ${ }^{-1} \mathrm{yr}^{-1}, 36.2 \mathrm{GJ} \mathrm{ton}^{-1}, 0.08 \mathrm{~kg} \mathrm{CO}_{2}$-eq MJ ${ }^{-1}$.

Paz and Vissers [106] made GHG calculations for a jatropha plantation in Mozambique. Although their result (48\% GHG reduction) is much more favourable than the plantation results reported here, they are mutually consistent because their estimate did not need to take account of land use change emissions, as jatropha was cultivated on an old tobacco estate. IFEU calculated GHG reductions for the same smallholder system in Tanzania and came to a saving of $444 \mathrm{~kg} \mathrm{CO} 2^{-}$ eq $\mathrm{ha}^{-1}$ (68\% GHG reduction) [107].

\subsection{Biodiversity}

The original vegetation in the area targeted to be cleared for the plantation consists of Eastern African Coastal Forest and Eastern miombo woodland; see Appendix F (App Fig. 6). In this area, seven tree species were found that are listed in the IUCN Red List of threatened species; see Appendix F (App Table 9). The plantation area is largely part of the so-called Northern Zanzibar-Inhambane coastal forest mosaic which is classified both as Critical Ecoregion and Biodiversity Hotspot. The southernmost part of the plantation is part of the Eastern miombo woodlands, which is also a Biodiversity Hotspot area. In the Northwest and Southeast, the plantation areas are bordered by forest reserves which belong to the Kilwa District Coastal Forest, which is classified as Key Biodiversity Area for its high degree of bird endemic species. The calculated Shannon and Sørensen indexes are shown in Table 10.

From these indexes it can be concluded that 'forest' has the highest biodiversity value and 'woodland' the lowest. The floristic composition of the sampled miombo woodlands is most similar to that of 'open forest', while the 'forest' and 'dense forest' categories also resemble each other. The average Shannon index of 2.18 for woodlands is relatively high, compared to the average value of 1.9 for largely undisturbed miombo woodlands found in Mozambique [108]. This is an indication that the woodlands investigated in this study are probably not 'degraded' in terms of biodiversity. For old- growth miombo woodlands in northern Zambia for example, Shannon index values of 2.17-2.19 were reported, while miombo coppice showed decreased values of 1.36-1.54 [109]. Considering the large share of plant species in the Eastern miombo Woodland ecoregion of $54 \%$ which is endemic for that region, it is important to preserve this ecoregion [82]. The plantation company is planning to clear ultimately 80.000 ha. No trees, except Baobabs, will be left standing. This will result in a strong decrease of local biodiversity and in a largely fragmented habitat, with expected negative impacts on the regional biodiversity, including unique ecosystems and species with restricted ranges.

There was no evidence found of threats to biodiversity if jatropha is planted in hedgerows of live fences. In Central America live fences can contribute to biodiversity, more than 160 species of birds, bats, dung beetles and butterflies were recorded, furthermore "live fences offer a means of increasing tree cover in fragmented agricultural landscapes that can be readily adopted by farmers" [110]. Windbreaks can significantly enhance the local deposition of tree and shrub seeds within the agricultural landscape by attracting seeddispersing birds from nearby forests [111]. However the specific value of jatropha trees in hedgerows in Tanzania would have to be further researched.

\section{Discussion and conclusions}

\subsection{Comparison of the two business models}

The key results of the comparison of the two jatropha business models are summarized in Table 11.These results convey that the choice of business model affects the socio-economic and environmental performance in many ways. The smallholder model scores much better on land rights, GHG balance and biodiversity and it reaches more people, whereas the plantation model creates more employment and higher (local prosperity) benefits for smaller numbers of people, and could

Table 10 - Biodiversity results for the plantation model.

\begin{tabular}{lccccc} 
& $\begin{array}{c}\text { Nr of IUCN Red list species } \\
\text { per class }\end{array}$ & $\begin{array}{c}\text { Nr of IUCN Red list individuals } \\
\text { per class }\end{array}$ & Shannon index & Sørensen index \\
\hline Woodland & 3 & 12 & 2.18 & & 0.55 \\
Open forest & 2 & 5 & 2.52 & 0.13 & 0.3 \\
Forest & 4 & 27 & 3.65 & 0.11 & 0.16 \\
Dense forest & 4 & 11 & 3.33 & 0.52 \\
\hline
\end{tabular}


Table 11 - Summary of the impacts on sustainability from the two business models.

Smallholder-based model

Socio-economic areas of concern

1. Economic viability performance

Positive but relatively low NPV (8

$\left.-18 \mathrm{M} \$ \mathrm{ha}^{-1}\right)$, IRR (14-18\%), PBP (12

$-13 \mathrm{y})$ and production costs

between 1.10 and $1.14 \$ l^{-1}$

2. Local prosperity

3. Labour and working conditions

4. Food security

5. Land ownership and land rights
Large outreach but lower contribution per person, more noneconomic impacts. 126 field jobs, 80,000-160,000 farmers

$140 \$$ year $^{-1}$. Total investment

$11 \mathrm{M} \$$, total expenses 77-130 M\$,

$11 \%$ of costs related to processing Difficult to regulate at farmers level, no irregularities observed Major issue in Tz; impact depends largely on household income Low direct effects
Plantation model
Environmental areas of concern

6. Greenhouse gas balance and carbon stock changes

7. Biodiversity
Hardly any land use change effects $151 \%$ reduction if no replacement or original vegetation

Increased if planted as a new hedge, but more research required
$+-$

Except when harvest is fully mechanized $\left(-3 \mathrm{M} \$ \mathrm{ha}^{-1}\right)$, the NPV is positive but relatively low; 15-41 M\$ ha ${ }^{-1}$, IRR $17-91 \%$, or $7 \%$ when harvest is mechanized). PBP 3->20 y, production costs $1.10-1.24 \$ \mathrm{l}^{-1}$ )

$+$ Contribution to employment can be substantial. 10,000-35,000 jobs. Total investment $32 \mathrm{M} \$$, total expenses 107 $-125 \mathrm{M} \$, 18-20 \%$ of costs related to processing

$+\quad$ Possible to regulate, no irregularities observed except in exit strategy

$+\quad$ Major issue in Tz; impact depends largely on household income

$+\quad$ Large risk of negative impacts, 34,500 ha of land transferred, compensation paid but low at 20-30 \$ ha $\mathrm{h}^{-1}$ (limited positive impact), also unclear whether money arrived at targeted group, 13 people displaced, loss of land rights after discontinuation (very negative)

$+$

Previous land use is the major issue, which is strongly location specific, $2 \%$ reduction but large uncertainty due to influence of removal of original vegetation

$+\quad$ Very location specific, in this case strong decrease in on-site biodiversity, habitat fragmentation and decreased connectivity. 7 threatened tree species, Shannon index 2.18

+: Positive impact, +-: neutral impact or both positive and negative, -: negative impact.

possibly obtain higher yields. Risks of substantial negative impacts of the smallholder model are modest, whereas the plantation model could lead to decreased food security, loss of land rights and biodiversity. This could permanently affect the livelihood situation of the local population. The low GHG savings for the plantation system are due to the clearing of original vegetation; results would be much better if forest and woodland areas are avoided. A smallholder system seems to give farmers a better feeling of participation and can stimulate local entrepreneurship. On the other hand, permanent employment opportunities at a plantation model are higher, and rural development can be stimulated.

The economic analysis shows similar (low) rates of profitability with current yields, and the larger upfront investment that is required by a jatropha plantation model makes such investments currently risky.

The downside of the smallholder model for the processor is that there is no secured supply even with contracted outgrowers, since honouring contracts is challenging in a developing country like Tanzania. The best approach is to pay an attractive price to farmers. This can be made possible by investing in efficient processing and adding value through selling of by-products.

Except for the financial feasibility and the environmental analysis, the comparison between these business models could also apply to other feedstocks that are used in hedges or plantations. Issues with for example land rights in Tanzania are generic to large land transfers in general in Africa. GHG balance and biodiversity calculations apply to the specific crop and location we have chosen; in a different location, the results will be different. Location specific data about yields, profits, employment requirements, poverty situation, labour availability and land use will always be required for this. Furthermore, the implementation of the models can influence the performance of the systems. Implementation aspects are project specific such as vision and strategies of management team, company values, and so on. Also the policy environment is an important factor for the implementation of potentially successful business models. Both companies that we used to represent the two models were focussed on the European market and therefore on the European sustainability regulations, e.g. RED. This might have been a reason for them to make sure that they applied a relatively sustainable business model.

\subsection{Framework accuracy}

The assessment framework is useful for early flagging of potential major areas of concern for implementation of plantations and smallholder (hedge) models, at a stage when 
corrective actions are still possible. However, the usefulness of indicators is partly constrained by limits on availability of data; while in certain other areas more/better indicators would be required to further operationalize the framework and obtain more accurate results. Locally practicable - not overcomplex and/or overly expensive - indicators for monitoring soil, water, and air impacts are especially required. Ongoing pilot tests of the GBEP indicators and the RSB framework are expected to contribute to developing these. Furthermore, performing repeated measurements over time will provide more details on the performance of projects. Capturing wider and longer-term impacts from bioenergy projects also requires a longer-term view of the interaction with its broader development setting, taking account of factors such as policy changes, large regional development projects (e.g. infrastructure) and natural disasters such as floods or droughts. Furthermore, it will be useful to extend comparisons to other business models, especially those aiming at increasing local rural energy access, as this will assist governments and other organizations in determining which model is most or least suitable for specific locations. However, we also need to keep in mind that more extensive analysis - in whatever direction - can also reduce the framework's practicability.

\subsection{Value of the framework for practice}

One major lesson arising from the analysis is that the speed of change is a factor that requires attention. A very rapid increase in the number of people employed on a plantation as envisaged in our plantation case could cause food, fuel and water prices to rise, as local (isolated) markets have insufficient time to adjust. Both business models are expected to grow to 80,000 ha, this is a large area for cultivation of a plant that began to be grown commercially only recently. For these two reasons a gradual expansion trajectory is preferred for both models, which enables adequate time for adaptations and learning by doing. Moreover, the government should require realistic, socially acceptable exit strategies to be incorporated in the business plans, including a guarantee of re-transfer of land rights to local communities (for plantations), and cooperation agreements with other local organizations that can guarantee the market for jatropha seeds (for smallholder systems). Mandating clear communication with the local population, documented in writing in the local language for reasons of transparency, can help involve local communities and could minimize negative public perceptions and confusion. Organizing farmers into supply cooperatives groups could be a helpful model to make sure that farmers understand the value of honouring contracts and receive proper training and adequate payment in a smallholder model; it may also create a sense of social belonging and increase their bargaining power. Local governments should make sure that contracts do not repress farmers, could play a role in the establishment of farmer cooperatives and channel their own extension services through these.

The issue of food security is highly complex and our analysis cannot pretend to go beyond identifying key differences in risks and opportunities between the two models with a broad brush approach. Still, useful insights for action arise from it: in addition to boosting incomes, there are other actions that biofuel operators may take to improve food security [55]. For example, biofuel operators could provide extension services that introduce improved farming techniques, crop diversification, and/or post-harvest processing and storage. Furthermore plantations can offer flexible working hours to ensure that household subsistence food production is not compromised. Large companies using costly inputs like inorganic fertilizers could sell these on to farmers at bulk prices, or allow their earth-working equipment to be used by local farming communities. They can help to connect small farmers to micro credit facilities. The maintenance of community woodlots could help provide fuelwood, and jatropha by-products could be made available as energy sources [13]. Finally, contributions to infrastructural development lead to easier market access, provide wider opportunities for regional development and create public goodwill.

\subsection{Economic viability issues}

There are still large uncertainties surrounding jatropha production (especially concerning feasible yields) because the commercial use of jatropha is still new. Most large scale plantation companies assume much higher yields in their business plans than what was assumed in the 'base case' estimate of our plantation model of 1 ton seeds per ha (against BioShape's own 6 tons). Therefore, most business plans have strategically predicted much more positive results in order to attract support from financial institutions, host governments, etc., whereas we wanted to show as much as possible the actual situation with current yields, costs and prices. Currently, only farmers with low opportunity costs for family labour can profit financially from jatropha cultivation, and then only if they use a low-input regime [43]. Processors, who are still struggling to reach their own break-even point, cannot (as yet) afford to pay them more remunerative seed prices.

It is to be expected that, like other crops at the beginning of their commercial cultivation, efforts in jatropha breeding will lead to higher yielding, more reliable varieties which will increase financial feasibility. Several breeding research initiatives are currently ongoing such as those by JATROPT [112] and QUINVITA, but results are only expected after several years. Efforts to improve harvesting efficiency (on plantations) and improve valorization of by-products could also boost profitability, such as experiments to use jatropha seedcake as an animal feed. Until results from these efforts materialize, the viability of jatropha cultivation in large plantation settings seems doubtful.

\subsection{Inevitability of sustainability trade-offs}

Business models that would generate no risks and no negative impacts on any area of concern would of course be preferred, however in practice such models do not exist. Compromises are always necessary, arising from sustainability trade-offs. In very poor regions, it is often a matter of hosting a large biofuel investor with all its pros and cons, or having no investment projects at all. This could mean a big tension between generating employment and incomes, or maintaining biodiversity. In the smallholder model, there is no less tension between ensuring adequate remuneration of farm labour on the one 
hand, and striving for an acceptable IRR/NPV of processing companies on the other. The value that is placed on each area of concern is location and actor-specific and is embedded in a cultural and political mindset. Hence there are no easy choices that everyone can readily agree on. A shift from the status quo will always result in winners and losers. However, the status quo is certainly also unsustainable because of severe poverty. In the light of this, sustainability certification schemes such as the RSB and NTA8080 can be viewed as extremely demanding, as they require a positive (or at least neutral) impact in all areas, whereas this can be impossible to achieve in reality.

Still, the application of our framework shows that measures can often be identified to either prevent unsustainable outcomes, or ensure that already unsustainable situations improve over time. For instance, domestic processing is very important for impacts on local prosperity, and this is something that governments can influence. Tanzania's experiences show the value of tightening export regulation and introducing some monitoring of foreign investors [113,114]. Proper land use planning that can prevent future land conflicts and introducing a strong regulatory framework for land are also key government intervention areas, also identified by HabibMintz [115]. The Tanzanian government is discussing agro ecological zoning for better land use planning [116], in the realization that the development of domestic biofuel activities - both smallholder-driven and plantation-based - should be embedded in sustainable agricultural development and land use planning.

\section{Acknowledgements}

We would like to thank Ruud van Eck and all staff from Diligent Tanzania Ltd., Pol Knops and Ina de Visser from BioShape and researchers Elisa Portale, Amanda Mitchell and Wiea van der Zwan. Furthermore we thank three anonymous reviewers who provided valuable comments. This study was partly funded by Agency NL under the DBM program, by the Global Environmental Facility (GEF) through the targeted research project "Global Assessments and Guidelines for Sustainable Liquid Biofuels Production in Developing Countries" (co-funded by UNIDO and UNEP/FAO), and by the Responsible Innovation research programme of the Netherlands Science Organisation (NWO).

\section{Appendix A to F. Supplementary data}

Supplementary data related to this article can be found at http://dx.doi.org/10.1016/j.biombioe.2013.10.005.

\section{R E F E R E N C E S}

[1] Romijn HA, Caniels MCJ. The Jatropha biofuels sector in Tanzania 2005-2009: Evolution towards sustainability? Research Policy 2011;40(4):618-36.
[2] Cotula L, Dyer N, Vermeulen S. Fuelling exclusion? The biofuels boom and poor people's access to land. London: IIED; 2008.

[3] Gordon-Maclean A, Laizer J, Harrison PJ, Shemdoe R. Biofuel Industry Study, Tanzania: an assessment of the current situation. Tanzania \& Sweden: World Wide Fund for Nature (WWF); 2008.

[4] GEXSI. Global market study on Jatropha. London, Berlin: GEXSI LLP; 2008.

[5] Openshaw K. A review of Jatropha curcas: an oil plant of unfulfilled promise. Biomass and Bioenergy 2000;19(1):1-15.

[6] Francis G, Edinger R, Becker K. A concept for simultaneous wasteland reclamation, fuel production, and socioeconomic development in degraded areas in India: Need, potential and perspectives of Jatropha plantations. Natural Resources Forum 2005;29:12-24.

[7] Brittaine R, Lutaladio N. Jatropha: A smallholder Bioenergy Crop, The potential for Pro-poor development. Rome: FAO; 2010.

[8] Van Eijck J, Smeets E, Jongschaap R, Romijn H, Balkema A. Jatropha assessment; agronomy, socio-economic issues and ecology, facts from literature. Utrecht: Copernicus Institute, Utrecht University, Eindhoven University of Technology and Wageningen PRI; 2010. Commisioned by NL Agency, http://www.agentschapnl.nl/content/report-jatrophaassessment.

[9] GTZ. Jatropha reality-check, a field assessment of the agronomic and economic viability of Jatropha and other oilseed crops in Kenya. Eschborn, Germany: Endelevu Energy, World Agroforestry Centre, Kenya Forestry Research Institute; 2009.

[10] World Bank. Placing the 2006/08 commodity price boom into perspective. The World Bank; 2010.

[11] Mitchell D. A note on rising food prices. Washington: World Bank; 2008.

[12] Ribeiro D, Matavel N. The jatropha trap? the realities of farming jatropha in Mozambique. Friends of the Earth Mozambique, Justica Ambiental and Uniao Nacional de Camponeses (UNAC); 2010.

[13] Loos TK. Socio-economic impact of a Jatropha - project on smallholder farmers in Mpanda, Tanzania [Master]. Hohenheim: University of Hohenheim; 2008.

[14] Endelevu energy. Jatropha reality-check. A field assessment of the agronomic and economic viability of jatropha and other oilseed crops in Kenya. Endelevu Energy, World Agroforestry Centre, Kenya Forestry Research Institute; 2009.

[15] Ariza-Montobbio P, Lele S. Jatropha plantations for biodiesel in Tamil Nadu, India: viability, livelihood trade-offs, and latent conflict. Ecological Economics 2010;70(2):189-95.

[16] Tomomatsu Y, Swallow B. Jatropha curcas biodiesel production in Africa: economics and potential value chain development for smallholder farmers. Nairobi: World Agroforestry Centre; 2007. p. 33.

[17] Finco MVA, Doppler W. Bioenergy and sustainable development: The dilemma of food security and climate change in the Brazilian savannah. Energy for Sustainable Development 2010;14(3):194-9.

[18] German L, Schoneveld GC, Gumbo D. The local social and environmental impacts of smallholder-based biofuel investments in Zambia. Ecology and Society 2011;16(4):12.

[19] Salfrais N. Small is beautiful? The impacts of small-scale bio fuel production on people's access to land in the Koulikoro Region, Mali. Utrecht: Utrecht University; 2010.

[20] Achten WMJ, Maes WH, Aerts R, Verchot L, Trabucco A, Mathijs E, et al. Jatropha: from global hype to local opportunity. Journal of Arid Environments 2010;74(1):164-5. 
[21] ProForestLtd. Jatropha literature and perspectives review: main potential social and environmental impacts arising from large scale plantings. Oxford, UK: ProForest Ltd.; 2008.

[22] Mota M. Potential changes in Mozambican farming systems due to Jatropha introduction for biodiesel. Wageningen, the Netherlands: Wageningen University; 2009.

[23] Peters F. Socio-economic Impact Study of biofuel plantation on farm households in Mozambique. Wageningen, the Netherlands: Wageningen University; 2009.

[24] Spöttle M, Vissers P, Zelt T. Sustainability assessment of Jatropha plantations in Mozambique. Jatropha Alliance (GEXSI, Partners for Innovations); 2011.

[25] Broadhurst T. Biofuels and sustainability: a case study from Tanzania. PISCES Working brief; 2011.

[26] van Dam J, Junginger M, Faaij APC. From the global efforts on certification of bioenergy towards an integrated approach based on sustainable land use planning. Renewable and Sustainable Energy Reviews 2010;14(9):2445-72.

[27] Cramer, et al. Criteria for sustainable biomass production. Energy Transition Task Force; 2006.

[28] Brose I, Stappen FV, Castiaux A. Articulation of environmental and socio-economic externalities from bioenergy. Management of Environmental Quality: An International Journal 2010;21(6):812-29.

[29] NEN. Dutch Technical Agreement, NTA8080, Sustainability criteria for biomass for energy purposes. Delft: Nederlands Normalisatie Instituut (NEN); 2009.

[30] RSB. Roundtable on sustainable biofuels (RSB), principles \& criteria for sustainable biofuel production, version 1.0. Lausanne: Roundtable on Sustainable Biofuels; 2009.

[31] GBEP. The global bioenergy partnership common methodological framework for GHG lifecycle analysis of bioenergy. version zero [cited 2010]. Available from, http:// www.globalbioenergy.org/?id=11856; 2009.

[32] 2009/28/EC D Directive 2009/28/EC of the European Parliament and of the council of 23 April 2009, on the promotion of the use of energy from renewable sources and amending and subsequently repealing Directives 2001/77/ EC and 2003/30/EC. Official Journal of the European Union 2009.

[33] WWF. WWF position paper on bioenergy. Available from, http://np-net.pbworks.com/f/WWF+(2008)+ Position+paper+on+bioenergy.pdf; 2008.

[34] MEM. Draft: guidelines for sustainable development of liquid biofuels and co-generation in Tanzania. Dar es Salaam; 2008.

[35] Vissers P, Paz A, Hanekamp E. How to select a biomass certification scheme. Utrecht, the Netherlands: Partners for Innovation BV, Agency NL; 2011.

[36] Froger E, Paz A, Vissers P. Selection of a sustainability standard for pilot assessments of Jatropha producers in Mozambique. Utrecht: NL Agency, Jatropha alliance, GEXI, Partners for Innovation BV, Elaion AG, Sun Biofuels Mozambique, Green Power and Agro-Pecuária de Manica Lds; 2010.

[37] Roks M. Size and sustainability. The treatment of smallholders in sustainability certification of biomass for energy purposes. Eindhoven: Eindhoven University of Technology; 2010.

[38] Ismail M, Rossi A, Geiger N. A compilation of bioenergy sustainability initiatives. update. Rome: Food and Agriculture Organization of the UN (FAO); 2011.

[39] RSB. RSB principles and criteria 05/11/2010. Version 2.0. Roundtable on Sustainable Biofuels (RSB); 2010.

[40] GBEP. Sustainability indicators for bioenergy. Global Bioenergy Partnership; 2011.
[41] Lewandowski I, Faaij APC. Steps towards the development of a certification system for sustainable bio-energy trade. Biomass and Bioenergy 2006;30(2):83-104.

[42] Smeets E, Junginger M, Faaij A, Walter A, Dolzan P, Turkenburg $W$. The sustainability of Brazilian ethanol-An assessment of the possibilities of certified production. Biomass and Bioenergy 2008; 32(8):781-813.

[43] van Eijck J, Smeets E, Faaij A. The economic performance of jatropha, cassava and Eucalyptus production systems for energy in an East African smallholder setting. GCB Bioenergy 2012;4(6):828-45.

[44] UNDP. Human development report. United Nations Development Programme; 2011.

[45] UNDP. Human development reports. United Nations Development Programme; 2009.

[46] Millennium development goals indicators [Internet]. Available from, http://unstats.un.org/unsd/mdg/Data.aspx? $\mathrm{cr}=834 ; 2011$.

[47] ILO. Tripartite declaration of principles concerning multinational enterprises and social policy (MNE Declaration). 4th ed. Geneva: International Labour Organization (ILO); 2006.

[48] Woods J, Diaz-Chavez R. The environmental certification of biofuels. London: Joint Transport Research Centre, OECD, International Transport Forum, Imperial College; 2007.

[49] Meredith JR, Mantel SJ. Project management. A managerial Approach. New York: John Wiley \& Sons, Inc.; 2011.

[50] RSB. RSB principles \& criteria for sustainable biofuel production. Lausanne, Switzerland: École Polytechnique Fédérale de Lausanne; 2010. Contract No.: RSB-IND-20-001 (version 2.0).

[51] McKinney P. Tanzania: comprehensive food security and vulnerability analysis (CFSVA). Rome, Italy: UN World Food Programme, Vulnerability Analysis and Mapping Branch (ODAV); 2006.

[52] UNICEF. Progress for children: a world fit for children statistical review. New York: United Nations Children's Fund; 2007.

[53] UNFAO. Special Programme for Food Security [cited 2010 March 11]. Available from, http://www.fao.org/spfs/aboutspfs/frequently-asked-questions-spfs/en/; 2010.

[54] FAO. Bioenergy and food security, the BEFS analytical framework. Rome: The Bioenergy and Food Security Project (BEFS), FAO; 2010.

[55] RSB. RSB food security guidelines. Lausaunne: The Roundtable for Sustainable Biofuels; 2011. Contract No.: RSB-GUI-01-006-01 (version 2.0).

[56] Sulle E, Nelson F. Biofuels, land access and rural livelihoods in Tanzania. London: IIED; 2009.

[57] Vermeulen S, Cotula L. Over the heads of local people: consultation, consent, and recompense in large-scale land deals for biofuels projects in Africa. Journal of Peasant Studies 2010;37(4):899-916.

[58] Sulle E, Nelson F. Developing commercial biofuels through securing local livelihoods and land rights. Tanzania Natural Resource Forum 20092009.

[59] Franke B, Reinhardt G, Malavelle J, Faaij A, Fritsche U. Global assessments and guidelines for sustainable liquid biofuels. A GEF targeted research project, organized by UNEP, FAO, UNIDO. Heidelberg, Paris, Utrecht, Darmstadt: IFEU, UNEP, Utrecht University, OEKO; 2012.

[60] Muukkonen P, Heiskanen J. Estimating biomass for boreal forests using ASTER satellite data combined with standwise forest inventory data. Remote Sensing of Environment 2005;99(4):434-47.

[61] Maselli F, Chiesi M, Moriondo M, Fibbi L, Bindi M, Running SW. Modelling the forest carbon budget of a 
Mediterranean region through the integration of ground and satellite data. Ecological Modelling 2009;220(3):330-42.

[62] Ribeiro NS, Saatchi SS, Shugart HH, Washington-Allen RA. Aboveground biomass and leaf area index (LAI) mapping for Niassa Reserve, northern Mozambique. Journal of Geophysical Research 2008;113(G3):G02S.

[63] Hennenberg KJ, Dragisic C, Haye S, Hewson J, Semroc B, Savy C, et al. The power of bioenergy-related standards to protect biodiversity. Conservation Biology 2010;24(2):412-23.

[64] WDPA. World database on protected areas, incorporating the UN list of protected areas - last update; 2010.

[65] Conservation International. Coastal Forests of Eastern Africa, -last update; 2007.

[66] IBAT. Integrated Biodiversity Assessment Tool (IBAT), Key Biodiversity Areas, -last update; 2008.

[67] WWF. Eastern Africa coastal forests - a global ecoregion -last update; 2010.

[68] Shannon CE. A mathematical theory of communication. Bell System Technical Journal 1948;27:379-423. 623-656.

[69] Sorensen TA. A method of establishing groups of equal amplitude in plant sociology based on similarity of species content, and its application to analyses of the vegetation on Danish commons. Kongelige Danske Videnskabernes Selskabs Biologiske Skrifter 1948;5:1-34.

[70] IUCN. The IUCN red list of threatened species [updated 20106-16-2010]. Available from, http://www.iucnredlist.org/; 2010.

[71] Jennings S, Nussbaum R, Judd N, Evans T. The high conservation value forest toolkit. Oxford, UK: ProForest; 2003.

[72] BioShape. BioShape Tanzania ltd. Business Plan. version 25. BioShape, Ecofys, AIDEnvironment, Ingenia and CE Delft; 2009.

[73] Household facilities [Internet]. Available from, http:// countrystat.org/home.aspx?c=TZA\&ta $=$ Q34.2A\&tr $=-2$; 2006

[74] FACT Foundation. The Jatropha handbook, from cultivation to application. Eindhoven: FACT foundation; 2010.

[75] Chachage C, Baha B. Accumulation by land dispossession and labour devaluation in Tanzania, the case of biofuel and forestry investments in Kilwa and Kilolo. Land rights research \& resources institute (Haki Ardhi); 2010.

[76] Portale E. Socio-economic sustainability of biofuel production in sub-Saharan Africa: Evidence from a Jatropha Outgrower Model in Rural Tanzania. Cambridge: Center for International Development, Mass: Harvard University; 2012.

[77] Diligent. Sustainable biofuel production in Tanzania, Business Plan. Eindhoven, the Netherlands: Diligent Energy Systems; 2008.

[78] Carrington D. UK firm's failed biofuel dream wrecks lives of Tanzania villagers, the collapse of Sun Biofuels has left hundreds of Tanzanians landless, jobless and in despair for the future. The Observer; 2011.

[79] Association of Tanzania employers. The publication of the regulation of wages and terms of employment order 2010; 2010. Dar es Salaam.

[80] Ministry of Finance and Economic Affairs. The economic survey 2009. Dar es Salaam; 2010.

[81] Mitchell A. The implications of smallholder cultivation of the biofuel crop, Jatropha curcas, for local food security and socio-economic development in northern Tanzania. London: University of London; 2008.

[82] van der Zwan W. Jatropha footprint, environmental and socio-economic impact of the BioShape project in Kilwa district, Tanzania. Utrecht: Utrecht University; 2011.

[83] Wa Simbeye F. Yono to auction BioShape property to recover workers' dues. Tanzania: DailyNews; 2011.
[84] Wa Simbeye F. High court blocks BioShape property's auctioning by Yono. DailyNews; 2011.

[85] FAO. Bioenergy and food secrurity. The BEFS Analysis for Tanzania. Rome: FAO; 2010.

[86] AIDEnvironment. Strategic impact assessment, Jatropha production in plantation areas in Kilwa district, Tanzania. Amsterdam: AIDEnvironment; 2007.

[87] Van Eijck J. Case Study: The smallholder model of biofuel production in Tanzania. Commissioned by GTZ and ProBEC; 2009.

[88] Wa Simbeye F. Minister tells investors to acquire land legally. Tanzania: Daily News; 2011.

[89] Valentino S. Tanzania Biofuel Project's Barren promise; 2011.

[90] Practical Action Consulting. Small-scale bioenergy initiatives: brief description and preliminary lessons on livelihood impacts from case studies in Asia, Latin America and Africa. Rome: Prepared for PISCES and FAO by Practical Action Consulting; 2009.

[91] Wahl N, Jamnadass R, Baur H, Munster C, Liyama M. Economic viability of Jatropha curcas L. plantations in Northern Tanzania, assessing farmers' prospects via costbenefit analysis. Nairobi: World Agroforestry Centre; 2009.

[92] ActionAid. Implication of biofuels production on food security in Tanzania. Dar es Salaam: ActionAid Tanzania; 2009.

[93] IPCC. IPCC Guidelines for National Greenhouse Gas Inventories. prepared by the National Greenhouse Gas Inventories Programme. Japan: IGES; 2006.

[94] Bailis R, McCarthy H. Carbon impacts of direct land use change in semiarid woodlands converted to biofuel plantations in India and Brazil. GCB Bioenergy 2011;3(6):449-60.

[95] Achten WMJ, Trabucco A, Maes WH, Verchot LV, Aerts R, Mathijs E, et al. Global greenhouse gas implications of land conversion to biofuel crop cultivation in arid and semi-arid lands - lessons learned from Jatropha. Journal of Arid Environments 2012;(0).

[96] Firdaus MS, Husni MHA. Planting Jatropha curcas on constrained land: emission and effects from land use change. The Scientific World Journal 2012;2012:7.

[97] JRC. Background guide for the calculation of land carbon stocks in the biofuels sustainability scheme. Drawing on the 2006 IPCC Guidelines for National Greenhouse Gas Inventories. Ispra, Italy: Joint Research Centre (JRC), Institute for Environment and Sustainability; 2010.

[98] Croezen H. Een broeikasgas analyse voor het Bioshape initiatief. Delft: CE Delft; 2008.

[99] Struijs J. Shinda Shinda, Option for sustainable bioenergy: a jatropha case study. Bilthoven: RIVM (National Institute for Public Health and the Environment); 2008. 607034001/ 2008.

[100] Hellings B, Romijn H, Franken YJ. Carbon storage in Jatropha curcas trees in Northern Tanzania. Eindhoven, the Netherlands: FACT Foundation; 2012.

[101] Reinhardt G, Gärtner S, Rettenmaier N, Münch J, Falkenstein Ev. Screening life cycle assessment of Jatropha biodiesel. Heidelberg: IFEU - Institute for Energy and Environmental Research Heidelberg GmbH; 2007.

[102] Reinhardt G, Becker K, Chaudhary DR, Chikara J, Falkenstein Ev, Francis G, et al. Basic data for Jatropha production and use - updated version. Heidelberg, Bhavnagar, Hohenheim: Institute for Energy and Environmental Research Heidelberg (IFEU), Central Salt \& Marine Chemicals Research Institute (CSMCRI), University of Hohenheim; 2008.

[103] Bergsma G, Vroonhof J, Dornburg V. A greenhouse gas calculation methodology for biomass-based electricity, heat 
and fuels - The view of the Cramer Commission. CE Delft; 2006.

[104] Hamelinck C, Koop K, Croezen H, Koper M, Kampman B, Bergsma G. Technical specification: greenhouse gas calculator for biofuels. Version 2.1b. Utrecht: Ecofys, CE, SenterNovem; 2008.

[105] Ryan CM, Williams M, Grace J. Above- and belowground carbon stocks in a Miombo Woodland Landscape of Mozambique. Biotropica 2011;43(4):423-32.

[106] Paz A, Vissers P. Greenhouse gas calculations Jatropha value chain Sun Biofuels Mozambique SA. Jatropha Alliance; 2011.

[107] Franke B, Reinhardt G, Malavelle J, Faaij A, Fritsche U. Global assessments and guidelines for sustainable liquid biofuels. A GEF targeted research project. Heidelberg, Paris, Utrecht, Darmstadt: IFEU, UNEP, Utrecht University, OEKO, FAO, UNIDO; 2011.

[108] Williams M, Ryan CM, Rees RM, Sambane E, Fernando J, Grace J. Carbon sequestration and biodiversity of regrowing Miombo woodlands in Mozambique. Forest Ecology and Management 2008;254(2):145-55.

[109] Chidumayo EN. Species Structure in Zambian Miombo Woodland. Journal of Tropical Ecology 1987;3(2): 109-18.

[110] Harvey CA, Villanueva C, Villacís J, Chacón M, Muñoz D, López M, et al. Contribution of live fences to the ecological integrity of agricultural landscapes.
Agriculture, Ecosystems \& Environment 2005; 111(1-4):200-30.

[111] Harvey CA. Windbreaks enhance seed dispersal into agricultural landscapes in Monteverde, Costa Rica. Ecological Applications 2000;10(1):155-73.

[112] JATROPT. Jatropha curcas applied and technological research on plant traits (JATROPT). Jatropha curcas breeding strategy - towards a sustainable crop for biomaterials and biofuels. Available from, http://cordis. europa.eu/fetch?CALLER=FP7_PROJ_EN\&ACTION= $\mathrm{D} \& \mathrm{DOC}=2 \& \mathrm{CAT}=\mathrm{PROJ} \& \mathrm{QUERY}=0129364 \mathrm{~b} 301 \mathrm{e}: \mathrm{faf4}$ : $0163115 c \& R C N=94718$.

[113] Bengesi K, Naiko E. Public fury halts biofuel onslaught on farmers. The EastAfrican; 2009.

[114] Ishengoma E, editor. Keynote adress. National Jatropha Conference 2011 2011. Arusha, Tanzania.

[115] Habib-Mintz N. Biofuel investment in Tanzania: Omissions in implementation. Energy Policy 2010;38(8):3985-97.

[116] Kiwele PM, editor. Public private partnership in energy and related biofuels projects. National Jatropha Conference. Arusha, Tanzania: JANI; 2011.

[117] Diaz-Chavez RA. Assessing biofuels: aiming for sustainable development or complying with the market? Energy Policy 2010;39(10):5763-9.

[118] Romijn HA. Land clearing and greenhouse gas emissions from Jatropha biofuels on African Miombo Woodlands. Energy Policy 2010;39(10):5751-62. 